\title{
The Eternal Territory? The Crimean Crisis and Ukraine's Territorial Integrity as an Unamendable Constitutional Principle
}

\author{
By Yaniv Roznai* \& Silvia Suteu ${ }^{* *}$
}

\begin{abstract}
This article reflects on the protection of territorial integrity in the Ukrainian constitution, especially on its provision of unamendability, against the backdrop of the 2014 Crimean crisis. At the general level, we examine whether constitutional theory can offer answers when confronted with the apparent inefficacy of a constitutional claim to eternity. More specifically, we focus on what the Ukrainian case can teach us about the implications of designating territorial integrity or indivisibility of a state as an eternal/unamendable constitutional principle. Building on insights from the Crimean crisis, we argue that the unamendable protection of territorial integrity is an especially ineffective type of eternity clause because it is subject to both the internal threat of secession and the external risk of forceful annexation. The preservative promise of unamendable territorial integrity is severely curtailed by this double vulnerability, even when backed by a constitutional court with far-reaching powers of judicial review. Territorial integrity as an eternal constitutional principle then remains merely aspirational. Moreover, we argue that the act of entrenching territorial protection as an unamendable principle is in clear tension with the idea of popular sovereignty and with mechanisms for expressing popular will.
\end{abstract}

East-Central European constitutions play like songs of the liturgy on a very old gramophone. You hear the expected music performed in the service of constitutionalism, but vou hear it with a crackle in the background. The performance is old-fashioned in order

\footnotetext{
"Post-Doctoral Fellow, Hauser Global Law Schoo, New York University (NYU); Research Director, Faculty af Law and Geography Department, Minerva Center for the Rule of Law Under Extreme Conditions, University of Haifa.

** Ph.D. Candidate, School of Law, University of Edinburgh; Associate Director for Research Engagement, Edinburgh Centre for Constitutional Law.

The authors wish to thank Sujit Choudhry, Samuel Issacharoff, Michel Rosenfeld, Andreas Kalyvas, Richard Albert, Gábor Halmai, William Partlett, Jan Kudrna, Ida Koivisto, Dominik Steiger, Bartosz Marciniak, Mykola Gnatovsky, Eoin Daly, and especially Zoran Oklopeic for useful comments and assistance during the preparation of this article. We also extend aur gratitude to the student editars of the German Law Journal who worked on this article: Aria Allan, Alyson Cox, Vincent Smith, Jocelyn Jezierny, Chi Ewusi, Andrea Marshall, Lizzy Williams, and Jessica Winn.
} 
to receive the nullo obstat of the Council of Europe and sometimes (when territorial integrity comes up) the soprano's voice suffers from hysteria. ${ }^{1}$

\section{A. Introduction}

Ukraine's 2014 crisis began as anti-governmental protests that led to the removal of Ukraine's former president, viktor Yanukovich in February 2014, after which pro-Russian militias in Crimea took control of strategic facilities and of Crimea's administrative borders with the rest of Ukraine. On 1 March 2014, the Russian State Duma approved a request by President Vladimir Putin to engage Russian forces in Ukraine in order to protect Russian lives. Later, Russian and pro-Russian forces gradually took over Ukrainian military sites and the main official institutions in Crimea. ${ }^{2}$ On 6 March 2014, the Supreme Council of the Autonomous Republic of Crimea adopted a resolution, "On the All-Crimean Referendum," on the basis of Articles 18(1)(7) and 26(2)(3) of the Crimean Constitution. ${ }^{3}$ This resolution was meant to provide the legal basis for a referendum on independence, to be held on 16 March 2014, but was promptly contested by Ukrainian and international voices. ${ }^{4}$ On 11 March 2014, Crimea's parliament approved a resolution on the independence of Crimea and "if a decision to become part of Russia [was] made at the referendum of the 16 March 2014." The resolution declared Crimea as an independent, sovereign state and requested the Russian Federation to accept the Republic of Crimea as a new constituent entity of the Russian Federation with a status of a republic. ${ }^{5}$

\footnotetext{
${ }^{1}$ András Sajó, Reforming Prince Potemkin, 2 E. Eur. Const. REv. 126, 126 (1993).

${ }^{2}$ See Ben Smith \& Daniel Harari, Ukraine, Crimea and Russia, House or COMMONS LIBRARY 1-6 (Mar. 17, 2014), http:/www. parliament.uk/business/publications/research/briefing-papers/RP14-16/ukraine-crimea-and-russia; Ivamna Bilych, Alexamder Gudko, Kateryna Kuntsevich, Matheus Sena, Malvika Seth \& Olena Sharvan, The Crisis in Ukroine: Its Legai Dimensions, RAzOM 34-35 (2014),
} https://s3.amazonaws.com/razominc/The_Crisis_Ir_Ukraine_-_Its_Legal_Dimensions.pdf.

"Article $18(1)(7)$ provides that the Autonomous Republic may "call and hold republican (local) referendums upon matters coming under the terms of reference of the Autonomous Republic af Crimea." THE CONSTITUTION OF THE AUTONOMOUS RePUBLLC Or CRIMEA Oct. 21, 1998, art. 18(1)(7). Crimean Constitution Article 26(2)(3) provides that the Supreme Council may "pass a resolution upon holding a republican (local) referendum." id. art. 26(2)(3).

${ }^{4}$ See Anne Peters, Sense and Nonserse of Territorial Referendurns in Ukraine, and Why the 16 Morch Referendum in Crimea Does Not Jastify Crimea's Alteration of Territorial Status under International LaW, EJlL: TALl, Apr. 16 2014, http:/www.eji talkorg/sense-and-nonsense-of-territorial-referendums-in-ukraine-and-why-the-16-marchreferendum-in-crimea-does-not-justify-crimeas-alteration-of-territorial-status-under-international-law/ (last visited June 16,2015$)$.

SSee Resolution 'On the independence of Crimea,' RT (Mar. 17, 2014, 15:09), http://rt.com/news/crimearesolution-independence-ukraine-346/ ( last visited June 16, 2015). 
The Ukrainian government did not recognize the referendum and declared it illegal. ${ }^{6}$ On 14 March 2014, the Ukrainian Constitutional Court found the Crimean referendum to be unconstitutional and ordered the Crimean authorities to immediately cease all preparations for it. ${ }^{7}$ On 20 March 2014, the same Court declared the resolution of the parliament of Crimea "on the declaration of independence ${ }^{\prime r}$ to be unconstitutional. ${ }^{8}$ On 15 March 2014, the Council of Europe's Venice Commission for Democracy through Law (Venice Commission) opined that the referendum would be unconstitutional and illegitimate. ${ }^{9}$ A draft United Nations Security Council resolution urging states not to recognize the results of the referendum failed to pass on 15 March 2014 following Russia's veto and China's abstention. ${ }^{10}$ On 27 March 2014, the United Nations General Assembly adopted Resolution $68 / 262$ in which it emphasized "that the referendum held in the Autonomous Republic of Crimea and the city of Sevastopol on 16 March 2014, having no validity, cannot form the basis for any alteration of the status of the Autonomous Republic of Crimea or of the city of Sevastopol." ${ }^{11}$

Notwithstanding these condemnations, on 16 March 2014, Crimea's local authorities held a referendum on whether Crimea should secede from Ukraine to join the Russian Federation. A day later, it was announced that 97 percent of the population had voted to join Russia. Consequently, the Russian President Vladimir Putin signed a decree recognizing Crimea as an independent state and singed agreements with Crimea's leadership declaring Crimea and the city of Sevastopol part of the Russian Federation. Subsequently, the Russian Parliament adopted a law accepting the new regions as parts of the Russian

\footnotetext{
'On 7 March 2014, acting President Turchynov signed a decree suspending the Crimean Parliament's Order of 6 March 2014 to hold a referendum on territorial integ rity and the Crimean Parliament's resolution authorizing the 16 March refarendum as violating the Ukrainian Constitution and laws. On 11 March 2014, the Ukrainian Parliament issued a statement demanding that the Crimean Parliament immediately revise its resolution to comply with the mational law. Moreover, Ukraine's Minister of Justice, Ombudsman and Chair of the Council of Judges, have al publicly condemned the referendum as unconstitutional. See Bilych et al., supra note 2, at 21.

${ }^{7}$ See Dec. of the Const. Ct. of Ukraine, No. 02-ro/2014 (Mar. 14, 2014).

"Dec, of the Const. Ct. of U/sraine, No. 03-rp/2014 (Mar. 20, 2014).

${ }^{3}$ See Venice Comm'n for Democracy Through Law, Opinion on "Whether the Decision Taken by the Supreme Council of the Autonomous Republic of Crimea in Ukraine to Organize a Referendum on Becoming a Constituent Territory of the Russian Federation or Restaring Crimea's 1992 Constitution is Compatibie with Constitutional Principles," COumal of Eur. (Mar. 21, 2014), http:/www.venice.coe.int/webforms/documents/default aspx?pdffile=CDL-AD(2014)002-e.

${ }^{10}$ See UN Security Council Action on Crimea Referendum Blocked, UN NEW5 CENTRE (Mar. 15, 2014), http:/www.un org/apps/news/story.asp?News/D=47362\#.VQHFPOFOghQ (last visited June 16, 2015).
}

${ }^{11}$ G.A. Res. 68/262, para. 5, U.N. Doc. A/RES/68/262 (Mar. 27, 2014). 
Federation. ${ }^{12}$ By March 2015, even President Putin was ready to admit that the plan "to bring Crimea back into Russia" had been orchestrated weeks before the referendum. ${ }^{13}$

The 2014 conflict surrounding the status of Crimea not only reflects a contentious political issue in Ukraine, in Russia and in between the two countries, ${ }^{14}$ but also raises imperative questions from the perspective of constitutional theory. Of those, one will be the particular focus of this contribution: the tension between the unamendable commitment to territorial integrity in Ukraine's constitution and the reality of the country's territorial fragmentation following the 2014 Crimean crisis. We are thus interested in the protection of territory, as inscribed in the eternity clause of Ukraine's constitution, as an instantiation of the question raised by Zoran Oklopcic in his contribution to this volume: "[W] hat happens to the authority of ... a constitutional order when a fluid and malleable identity fractures and disappears, and when competing political identities crystalize, instead?"15

This article reflects on the protection of territorial integrity in the Ukrainian constitution, and especially within its provision of unamendability, against the backdrop of the 2014 Crimean crisis. At the general level, we examine if constitutional theory can offer answers when confronted with the apparent inefficacy of a constitutional claim to eternity. More specifically, we focus on what the Ukrainian case can teach us about the implications of designating territorial integrity or indivisibility as an eternal/unamendable constitutional

\footnotetext{
${ }^{12}$ See Human Rights Watch, RIGHTS IN RETREAT: Aguses IN CRIMEA 35 (2014). The historic and ethric relationship shared by Russia and Crimea could explain the interest and the will of the government in Moscow to act an behalf of the Russian community in the Crimea, and conversely a sympathy within Crimea towards Russia. See, e.g., Philip Chase, Conflict in the Crimea: An Examination of Ethnic Conflict Under the Contemporary Model of Sovereignty, 34 ColuM. J. TRANsNAT'L L. 219, 227-29, 243 (1996); Roman Solchanyk, Crimea: Between Ukraine and Russio, in Crimen: DyNMmics, Challenges And ProspeCts 3, 4 (Maria Drohobycky ed., 1995). For a study on the trust-building between the Crimean population and Russia and the promotion of pro-Russian separatism in Crimea, see Lada L. Roslycky, Russia's Smort Power in Crimea: Sowing the Seed's of Trust, 11 SOUTHENST EUR. \& BLACK SEA STUdS. 299 (2011).

13 Putin Reveals Secrets of Russia's Crimeo Takeover Plot, BBC NEWs (Mar. 9, 2015), http:/Www. abc.co.uk/news/world-europe-31796226 (last visited June 16, 2015).

${ }^{14}$ See generally Chase, supra nate 12; Natalie Mychajlyszyn, The OSCE in Crimea, 9 Helsinkı Monitor 30, 36-37 (1998); Doris Wydra, The Crimeo Conundrum: The Tug of Wor Between Russid and Ukroine on the Questions of Autonomy and Self-Determination, 10 INI'L J. Minority \& Group RTs. 111 (2003); David R. Marples \& David F. Duke,

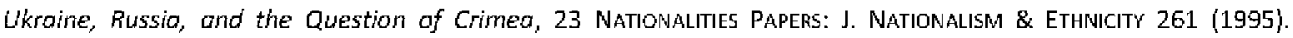
Interestingly, it has been argued that the primary source of instability in Crimea lies with Ulkraimian political and commercial interests and not with ethnic claims or geopolities. See Tetyana Malyarenko \& David J. Galbreath, Crimea: Competing Self-Determination Movements and the Politics at the Centre, 65 EUROPE-ASIn STUDS. 912 (2013).

${ }^{15}$ See Zoran Oklopeic, The idea of Early-Conflict Constitution-Making: The Conflict in Ukraine Beyond Territorial Rights and Constitutional paradoxes, 16 German L.J. 658, 659 (2015).
} 
principle. ${ }^{15}$ Building on insights from the Crimean crisis, we argue that the unamendable protection of territorial integrity is an especially ineffective type of eternity clause because it is subject to both the internal threat of secession and the external risk of forceful annexation. The preservative promise of unamendable territorial integrity is severely curtailed by this double vulnerability, even when backed by a constitutional court with farreaching powers of judicial review. Territorial integrity as an eternal constitutional principle then remains merely aspirational. Moreover, we contend that the act of entrenching territorial protection as an unamendable principle is in clear tension with the idea of popular sovereignty and with mechanisms for expressing popular will. This tension provides further evidence to support Stephen Tierney's insight that the principle of democracy is deeply unsettling for constitutional law. ${ }^{17}$ The uncertainty surrounding territorial change in constitutional law and theory, we conclude, is not alleviated by unamendable protections of territorial integrity.

The article proceeds by an examination of the constitutional protection of territorial integrity in Ukraine's constitutional architecture in Section B. We do so in several steps. First, we explore Ukraine's general constitutional arrangements of territorial organization and Crimea's place within those. Second, we focus on the unamendability protection of the territorial integrity within the Ukrainian constitution. Third, we study the concurrent adoption of constitutional review of proposed constitutional amendments in Ukraine and its relevance to the protection of unamendability. In Section $\mathrm{C}$ we outline the functions of unamendable constitutional provisions and further analyze the unamendability of territorial integrity in a comparative perspective. Section $D$ builds on insights from the previous sections in order to draw out major lessons from the Crimean crisis, regarding the tension between popular sovereignty and commitments to unamendability of the territorial integrity, as well as the limited effectiveness and risks of unamendability in the area of territorial integrity.

\footnotetext{
${ }^{1 h}$ In this paper, we use the term unamendability to describe the limitation on the constitutional amendment power from amending certain principles or institutions. Provisions which explicitly protect constitutional subjects from amendments are often termed "eternity clauses." For a nate on this terminology and its narmative implication, see Yaniv Roznai, Unamendability and the Genetic Code of the Constitution, Eur. Rev. Puk. L. (forthcoming 2015). Also, we use the terms "territorial indivisibility" and "territorial integrity" interchangeably. Nevertheless, it can be argued that there is a distinction between territorial indivisibility and territorial integrity. The former emphasizes the negation of secession whereas the latter carries a dual aspect: Internal-which opposes secession-and external-which emphasizes protection against foreign aggression or forcible encroachment of the territory. See Venice Comm'n for Democracy Through Law, Self-Determination and Secession in Constitutional Law, CouNcIL or EUR. (Jan. 12, 2000), http://www.venice.coe.int/webforms/documents/default.aspx?pdffile=CDL-INF(2000)002-e.

${ }^{17}$ See generally, Stephen Tierney, Sovereignty and Crimea: How Referendum Democracy Complicates Constituent Power in Muitinational Societies, 16 German L.J. 523 (2015).
} 


\section{B. Ukraine and the Unamendability of Territorial Integrity}

\section{Territorial Arrangements in the Ukrainian Constitution}

Constitutional commentators tend to ignore the territorial question surrounding the (re-)emergence of a state, instead tending to grapple with the question of who is "we, the people." ${ }^{18}$ Thus, it is perhaps surprising to note that a complex definitional attempt was not made at the time of Ukraine's independence, which some scholars have termed an "overwhelming indifference to the so-called 'national question," that is, who and on what terms constituted the "nation." 19 Others have pointed to the Ukrainian leaders' rejection of notions of "Ukraine for Ukrainians" and their adherence instead to a project of "statehood for all of its peoples" at that time; this in turn is said to have resulted in an overwhelming vate in favor of independence. ${ }^{20}$ What resulted in the early days of independence was thus "a pluralist, civic approach to the conception of a political community," and ethnos was shunned in favor of "a political-territorial conception of nationhood." 21

Once the constitution-making process got under way in the mid-nineties, however, the question on the nature of the political community displayed its true contested colors. Pitted against each other were the political right in Ukraine, with its emphasis on the "Ukrainian people" as the distinctive and titular majority, and the political left, which spoke of the "people of Ukraine" in an attempt to define it in territorial terms. ${ }^{22}$ According to the former, national minorities were accepted and protected as "state-forming communities," but the new civic nation was to be built around the core, Ukrainian ethnos. ${ }^{23}$ Conversely, the Left wanted a supra-ethnic definition of the people, wherein multi-ethnicity could be asserted and preserved. ${ }^{24}$

Without a centrist alternative and needing to reach a compromise, the Right's position was enshrined in the Ukrainian constitution, notably in its preamble and provisions on state

\footnotetext{
${ }^{18}$ An exception here is Zoran Oklopcic, provincializing Constitutional Pluralism, 5 Tran5NaT'L LEGAL THEORY 331-63 (2014).

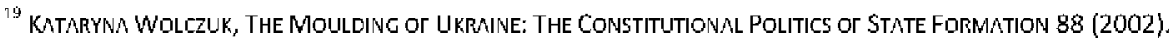

20 See Roman Solchanyk, The Politics of State Buidding: Centre-Periphery Relations in Post-Soviet Ukraine, 46 EUROPE-A5IASTULS. 47, 65 (1994).

21 Wolczuk, supra nate 19 , at 90.

${ }^{22}$ id. at $167-232$.

${ }^{23} \mathrm{ld}$. at 171.

24 Id.
} 
language and symbols. ${ }^{25}$ For this reason, some have listed Ukraine among those post-communist countries having enshrined "a dubious and contested definition of nationhood" in their constitution. ${ }^{25}$ More importantly, this brief foray into the debates surrounding constitution-drafting in Ukraine highlights the disputed nature of the political community in whose name the constitutional text was to be enacted. Such clashes between "competing and mutually exclusive models of statehood" ${ }^{27}$ serve to further illustrate the incursions between state and constitution-making which Oklopcic and Arato both discuss in this volume. ${ }^{28}$ As we note below, the constitutional arrangements surrounding Crimea's status further strengthened this notion of a civic state, ${ }^{25}$ to the exclusion of competing - and not insignificant-visions. ${ }^{30}$

The territorial question relates not just to the enforcement of external boundaries which statehood requires, but also to the internal administrative map reflecting or holding together the polity. This internal structure is occasionally also shrouded in unamendability, whether of the unitary state, such as in Romania, or of the federal structure, such as in Germany and Brazil. ${ }^{31}$ While Ukraine's provision of unamendability speaks of "territorial indivisibility" without further specifications, ${ }^{32}$ Article 2 of the constitution defines Ukraine as a unitary state and refers to its territory "within its present borders" as indivisible and inviolable. A short excursion into Ukraine's territorial arrangements, and the special status afforded Crimea, will, however, reveal the borders to have been less clear-cut.

${ }^{2 h}$ id. Although the preamble speaks of "the Ukrainian people-citizens of Ukraine of all nationalities," thus seerringly striking a compromise between the two positions, other provisions in the constitution, for example Article 11, refer to the centrality of the ukraimiam nation to the state and the latter's duty to support its consolidation and development. See Wolczuk, supra note 19, at 228.

${ }^{25}$ Irina Culic, State Building and Constitution Writing in Central and Eastern Europe After 1989, 1 Reglo MiNORITIES, POL., SOC'Y 56 (2003).

${ }^{27}$ WoLCZUK, supro note 19 , at 180.

${ }^{28}$ See Oklopcic, supra note 15. See generolly, Andrew Arato, international Role in State-Making in Ukraine: The Promise of a Two-Stage Constituent Process 16 GFRMAN L.I. 691 (2015); Culic, supra note 26, at 57 (speaking of state-building in post-communist states as "vigorous nation building" associated to a "remedial and assertive nationalism"i.

${ }^{29}$ See Wolczuk, supra note 19 , at 95.

${ }^{30}$ On the process of narrative construction of national identity in Ukraine, see Karina V. Korostelina, Mopping National identity Narratives in Ukraine, 41 NatIONALITIES PAPERS: J. NATIONAIISM \& ETHNICITY 293 (2013).

${ }^{31}$ For comparative studies on unamendability, see Marie-Francolse Rigaux, La Théorie des Limites Laterielles A L'EXERCICE DE LA FONCTION CONSTITUNATE (1985); Sharan weintal, Etermal Clauses in the constitution (2005) (unpublished Ph.D. thesis, Hebrew University of Jerusalem) (on file with authors); Yaniv Roznai, Unconstitutional Constitutional Amendments: A Study of the Nature and Limits of Constitutional Amendment Powers (2014) (urpublished D.Phil. thesis, Londan School of Economics and Political Science) (on file with authors); Richard Albert, Constitutional Hondcuffs, 42 ARIz. ST. L. J. 663 (2010).

:32 See infra Section B.II. 
Territorial integrity, as a central feature within Ukrainian constitutionalism, already appeared in the 1990 Declaration of the State Sovereignty of Ukraine alongside other important principles such as national state sovereignty and self-determirnation. ${ }^{33}$ The Act of Ukraine's Independence Declaration of August 1991 expressly states that "the territory of Ukraine is integral and inviolable..$^{\prime 34}$ The principle continued to be a central feature during the constitution-making process. The draft constitution of 27 Mav 1993 embodied the "fundamental political accommodation made to Crimea over the spring and summer of 1992 to curb the threat of Crimean secession." 26 October 1993, the first chapter entitled "Fundamentals of Constitutional Order" was modified to "General Provisions" and extended by the addition of various articles. Ukraine's sovereignty was added in Article 2, and its second part was complemented with the statement on the integrity and inviolability of the territory of the state. ${ }^{36}$ Territorial integrity is considered such an important public interest that it is also recognized in the constitution-alongside national security and public order-as a legitimate interest which justifies the limitation of fundamental rights, such as freedom of thought and speech. ${ }^{37}$

Chapter IX of the Ukrainian constitution of 1996 specifies the state's territorial structure. According to Article 132 "the territorial structure of Ukraine is based on the principles of unity and integrity of state territory [and] combination of centralization and decentralization in the exercise of state power." ${ }^{38}$ According to Article 133, "the system of the administrative and territorial structure of Ukraine is composed of the Autonomous Republic of Crimea, oblasts, districts, cities, city districts, settlements and villages." ${ }^{39}$

Ukraine's choice of a unitary territorial model was not inevitable. Indeed, as one author put it, "[a]t first sight, Ukraine is custom-made for far-reaching regionalization or even federalism. ${ }^{\prime 10}$ The same author describes the eventual choice for a unitary state as

\footnotetext{
${ }^{33}$ See Declaration of STATE SOVereigntr (Ukr. 1990).

34 Paul R. Mngocsi, A History or Ukraine: The LANo and Its Peoples 723 (2010) (citimg Declaration or independence (Ukr. 1991)).

${ }^{35}$ Keenan H. Hohol, The Droft Constitution of Ukraine: An Overview, 1 REV. CONST. STUD. 246, 276 (1993-1994).

3h See V. Shapoval, History of Constitutiona Organization of Modern ukrainian State, 2011 L. UKR. LECML J. 385, 410 (2011).

${ }^{37}$ See UKR interpretation of the Citizens' Rights Provisions, 31 CASE W. RES. J. INT'L L. 169, 190-92 (1999).

${ }^{38}$ UKRAYNSKa KONSTITUZIYA, June 28,1996 , ch. IX, art. 132 (U)kr.).

${ }^{39}$ On local govermments in Ukraine, see 5. Seriogina, Constitutional-Legal Regulation of Local Self-Government in Ukraine and Directions for its Improvement, 2012 L. UkR. LEGAL J. 65.

${ }^{40}$ Kataryna Wolczuk, Catching up with 'Eurape'? Constitutional Debates on the Territorial-Administrotive Model in independent Ukraine, 12 REGIONAL \& FED. STuD5. 65 (2002).
} 
stemming from a desire to "return to Europe," but in the early days of independence, Ukraine's political elites wavered between centralization and federalism. The latter was promoted by its supporters as a solution to regional economic needs, as a means to bolster the democratic credentials of the new state, and as an answer to multi-ethnicity. ${ }^{41}$ The federal idea was lost during constitutional drafting for several reasons. Strategically, its supporters appear to have failed to put forth an alliance to promote it. ${ }^{42}$ More fundamentally, however, it was seen as a destabilizing force-in the former federal Soviet Union, resulting in dissolution; ${ }^{43}$ In Russia, given the bloodv experience with separatist forces and in Ukraine, on account of federalism's potential to perpetuate, mobilize and legitimate centrifugal forces in the country." As Oleh Protsyk describes it, "the unwillingness to decentralize also was informed by expectations that such a policy would intensify destructive centrifugal tendencies in a polity that was only recently established and whose regional differences were strong and well-articulated." ${ }^{45}$ Federalism thus. became taboo for the political establishment. ${ }^{46}$ In the end, a unitary territory was perceived to be more likely to lead to an integrated society and to subordinate sub-state interests to those of the center. ${ }^{47}$ Within this unitary framework, decentralization and the regulation of self-government were also left underdeveloped, not so much "for a fear of rigidity and over-regulation, but rather the lack of a coherent conception of the territorial distribution of power and centre-periphery relations. ${ }^{48}$

The striking exception to all this is Crimea, which enjoys-as the only region where the majority of the population belongs to an ethnic minority-a special status with significant independence, albeit remaining a constituent part of Ukraine. ${ }^{49}$ The historical background

${ }^{41}$ See WolczUk, supra nate 19 , at 151.

${ }^{42}$ See id. at 152 .

${ }^{43}$ This is also reflected in the fact that of all former Soviet states, only Russia has a federal structure today. Interestingly, in a first attempt of constitutionalism initiated by the Tsar in an effort to maintain order and authority, the Russian Fundamental Laws of 1906 declared, "[T] he Russian state is one and indivisible." Wiliam Partlett \& Eric Ip, The Death of Socialist Law? (2015) (unpublished paper) (on file with authors).

${ }^{44}$ See Wolczuk, supra note 19, at 153-54; see oiso Gwendolyn Sasse, The 'New' Ukraine: A State of Regions, 11 RECIONAL \& FED. STUDS. 69, 82 (2001).

4. Oleh Protsyk, Majority-Minority Relations in the Ukraine, J. ETHNOPOLITCS \& MiNoriTy I5.5uES Eur. 1, 8 (2008), http://www.ermi.de/fileadmin/down/oads/oualications/JEMIE/2008/issue\%201/1-2008-Protsyk.pdf.

4h See Sasse, supra note 44, at 81; GWendolyn SMSSE, THe Crimen Question: IDENTITY, TRANSition, MND CONTLICT $25-26$ (2007); see oiso Bohdan A. Futey, Ukraine's Draft Constitution Meets Political Reality, 2 E. EUR. CONST. REv. 15 (1993).

4' See Wolczuk, supra note 19, at 244.

48 id. at 241 .

49 See Bilvch et al., supra note 2, at 20-21; Gwendolyn Sasse, Conflict Prevention in a Transition Stote: The Crimean issue in Past-Soviet Uikraine, 8 Nationalism \& EthNiC POL. 1, 1-26 (2002). 
is important. Crimea has held a special status both in the USSR and in independent Ukraine. Its multiethnic composition and geostrategic location have ensured this throughout its modern history, with the region being granted a special autonomy status at various times in its history. ${ }^{50}$ The region's ethno-territorial distinctiveness, in fact, has been said to provide the rationale for its post-Soviet autonomy, even if the latter has been "defined in territorial rather than ethnic terms." In 1954, the Soviet Union transferred the Crimean peninsula from the Russian Socialist Federative Soviet Republic to the administration of the Ukrainian Soviet Socialist Republic. This marked what some have termed "the real beginning of Crimea's link to the Ukrainian state." 52 Known as the "gift," the rationale for this transfer remains elusive, and its continued currency in Russian and Ukrainian politics makes Crimea an example "of how some Soviet-era decisions, especially those involving boundary changes or shifts in competences, assumed a radically different dynamic in the post-Soviet era. ${ }^{.53}$ Subsequent to the transfer, Crimea became a territory of the Ukrainian Soviet Socialist Republic within the Soviet Union and remained so for thirty-seven years until 1991 with the collapse of the USSR. When Ukraine gained its status as an independent nation, Crimea's status was constitutionally renegotiated in what turned out to be a protracted process. ${ }^{54}$ It was finally granted the status of an "autonomous republic" with the 1996 adoption of the Ukrainian constitution.

The initial draft of the Ukrainian Constitution comprised of merely limited autonomy rights granting Crimea the status of a rayon, but a constitutional framework was created especially for the Autonomous Republic of Crimea within Chapter $X$ of the new constitution. $^{5.5}$ The protracted negotiation process between the center and Crimean authorities, culminating in granting the region this autonomy status and the adoption of its constitution in 1998, has been pointed to as a potential explanation for the avoidance of conflict in the region in the aftermath of Ukraine's independence. Gwendolyn Sasse has made this argument, explaining that the stop-go institutionalization of Crimean autonomy post-1990 played an important conflict-preventing role. ${ }^{56}$ The process was mired in confusion over who exercised legitimate authority in the region, she argues, but the very fact that power players attempted to resolve the issue constitutionally is significant. ${ }^{57}$

\footnotetext{
${ }^{50}$ See SNSSE, supro note 46 , at 83.

"1d. at 106 .

52 id.

${ }^{3}$ Id. at 96 .

${ }^{34}$ See id. at $175-200$.

${ }^{55}$ See Wydra, supra note 14 , at 124.

${ }^{5 \sigma}$ See SNSSE, supra nate 46 , at 10.

"See id. at 175 .
} 
Chapter $X$ regulates the relations between Ukraine and Crimea and defines the regional legal authority of Simferopol vis-à-vis the central government in Kiev. It emphasizes the territorial unity of Ukraine and defines Crimea as an inseparable constituent part of Ukraine. Crimea's authority is determined by, limited by and derived from the Ukrainian constitution. While Crimea is entitled to have its own constitution, neither the latter nor other laws can contradict the constitution or the laws of Ukraine. ${ }^{58}$ According to Article 136, the authority, procedures and operation of Crimea's governmental institutions are determined by the constitution and laws of Ukraine and by legal acts of the Verkhovna Rada [Parliament] of the Autonomous Republic of Crimea according to its competencies, which are mainly of local importance. ${ }^{59}$

In the same vein, the Crimean constitution's first Article declares that the Autonomous Republic is an integral part of Ukraine and must govern itself in accordance with the constitution. ${ }^{60}$ Article 2(2) of the constitution expressly states that in a conflict between normative acts of the Republic of Crimea and the constitution of Ulcraine, the latter prevails because it is supreme over all other laws and regulations. ${ }^{61}$ This precedence can be illustrated with at least one significant decision of the Ukrainian Constitutional Court, which in 2001 invalidated parts of four Crimean normative acts and declared that only the Verkhovna Rada in Kiev could be called "parliament"; the Crimean Verkhovna Rada was merely the "representative organ" of the Autonomous Republic of Crimea and the region's constitution one of its many "normative-legal acts." Moreover, the Crimean constitution invokes "state guarantees of the status, powers and the right of property of the Autonomous Republic of Crimea," a clear effort on the part of regional authorities to prevent any downgrading of the region's status. ${ }^{63}$ However, there is nothing to echo this in the Ukrainian constitution, leaving the region's status vulnerable to action taken at the center. $^{54}$

\footnotetext{
58 See UKRAYNSKA KONSTITUZIYA June 28, 1996, ch. X, art. 135 (Ukr.); see also Bilych et al, supra note 2, at $20-21$.

${ }^{\text {h9 }}$ See UKRnYNSKA KONSTITUzIYA June 28,1996 , ch. $X$, art. 137 (Ukr.); Wydra, supra note 14 , at 124-25.

${ }^{60}$ See The Constitution of the Autonomous Repubic of Crimea. Oct. 21, 1998, ch. 1, art. 1.

${ }^{6}$ See id. ch. 1, art. 2(2).

F.2 Dec of the Const. Ct. of Ukraine, No. 01-pp/2001 (Feb. 27, 2001). See also SAsse, supra note 46, at 206.

${ }^{63}$ The Consititution of THe Autonomous Repubuc of Crimiea Oct. 21, 1998, ch. 1, art. 3(2); see Sasse, supra note 46, at 202.

${ }^{\text {fit }}$ See SAsse, supra note 46 , at 204.
} 
The constitutional commitment to a unitary state "a priori excludes any form of local, territorial autonomy of a federal type. ${ }^{+555}$ As such, the existence of the Autonomous Region of Crimea within a state so ardently declared unitary highlights the potentially contradictory nature of Ukraine's state-building project: "strengthening central state capacity within an institutionalized state unit inherited from the Soviet period, while simultaneously engaging with sub-national demands for more autonomy." ${ }^{66}$ The tension between centralization and decentralization was inscribed in the Ukrainian constitution when the asymmetric autonomy arrangement was set up. ${ }^{67}$ Thus, the special status of Crimea has led commentators to refer to Ukraine as a "state of regions," an example of a "federalized society," or a "regionalized unitary state." ${ }^{168}$ This was met with skepticism by those worried it would result in "years of constitutional litigation and political instability" ${ }^{\text {" } 99}$ but could also be seen as an unavoidable compromise given Crimea's historical separateness. Moreover, authors like Sasse writing before the 2014 crisis saw this only partially elaborated autonomous status as a guarantee of Crimea posing "less of a threat to the Ukrainian state, and [being] therefore less likely to be contested or eroded by the center" $;^{70}$ in other words, part of a "Iong game" Kiev played with Crimea in order to weaken the regionalist and separatist movements within the region. ${ }^{71}$

Even when there is no contradiction between provisions on the center versus on Crimea, vagueness in the national constitution is problematic. The latter's generic references to the ability of Crimea to self-govern result in Crimean authority remaining dependent on Kiev's goodwill. $^{72}$ On the one hand, after the adoption of the Ukrainian constitution that recognized and constitutionalized Crimea's special autonomous status and the approval of the Crimean constitution by the Ukrainian Parliament, it appeared that the situation had

\footnotetext{
is Paul Blakker, Constitutional Politics, Constitutional Texts and Democratic Variety in Central and Eastern Europe 20-221 (Sussex European Institute, Working Paper No. 105, 2008).

fih Sasse, supra note 44 , at 70 .

${ }^{67} 10$.

${ }^{68} / d$. at 69,96 .

59 Hohol, supra note 35, at 276-77 (citing Marc Lalonde, Second Symposium Notes (June 20-22, 1993) (urpublished symposium notes, International Symposium on the Draft Constitution of Ukraine)).

${ }^{70}$ SASSE, supro note 46 , at 256

1.d. at 255 .

72 The Venice Commission, commenting an Ukraine's 1996 constitutional draft, remarked that it "does nat have many provisions on the matter [of crimean autonomy] and leaves a large space of discretion to the Ukrainian legislator." Venice Comm'n for Democracy Through Law, Opinion on the Droft Constitution of Ukraine, Council of Eur. 17 (May 21, 1996), http://www.venice.coe.int/webforms/doruments/default.aspx?pdffile=CDLINF(1996)006-e (last visited June 16, 2015).
} 
been stabilized and that "secession is no longer ar issue where Crimea is concerned." ${ }^{37}$ On the other hand, notwithstanding its autonomous status, Crimea remained in a constant political struggle with the center over the basics of governing. ${ }^{74}$ Its different political options were evident during the 2002 demonstrations and the 2004 Orange Revolution, for instance, both of which seemed to "largely bypass[] Crimea." 75

\section{Territorial integrity as an Unamendable Principle in the Ukrainian Constitution}

Ukrainian formal amendment procedure creates a constitutional hierarchy. At the bottom, there is a low threshold for ordinary constitutional amendments which requires proposal by either the President or one-third of the national legislature, adoption by a majority of the national legislature, followed by a subsequent two thirds vote in the national legislature. At the middle level of the hierarchy, the constitution necessitates a proposal by either the President or two-thirds of the national legislature, adoption again by a two thirds vote in the national legislature, and ratification via national referendum in order to amend the constitution's general principles, rules of elections and referendums, and the amendment procedure itself. Finally, at the summit of the constitutional hierarchy, there are human rights and freedoms, national independence, and territorial integrity which are formally unamendable." As Article 157 of the 1996 constitution stipulates: "The Constitution of Ukraine shall not be amended if the amendments foresee the abolition or restriction of human and citizens' rights and freedoms, or if they are oriented toward the liquidation of the independence or violation of the territorial indivisibility of Ukraine." 77 The unamendable provision thus protects fundamental rights and the independence and territorial indivisibility of Ukraine from infringements by constitutional amendments. ${ }^{78}$

Should this limitation on the ability to amend the constitution as stipulated in Article 157 be regarded as an eternity clause? This question arises because the unamendability is formulated as a principle-which is mare a generalized guideline-rather than as a rule

\footnotetext{
${ }^{73}$ Mychajlyszyn, supra note 14, at 36-37. Sasse, writing in 2007, also declared that "Kyiv has managed to integrate Crimea into the new Ukrainian polity." SASSE, supra nate 46 , at 3.

${ }^{74}$ See Robert Agranoff, Autonomy, Devolution and Intergovernmentol Relations, 14 REgIONAL \& FED. STUDS. 26, 38 (2004).

${ }^{75}$ SAS5E, supra note 46 , at 219.

${ }^{76}$ UKRAYN ska Konstmuzlra June 28, 1996, ch. XIll, art. 154-57 (Ukr.). See Richard Albert, The Expressive Function of Constitutional Amendment Rules, 59 McGILL L. J. 225, 255-56 (2013).

77 UkRaynska KonstmuzlYa June 28, 1996, ch. XIII, art. 157 (Ukr.).

${ }^{78}$ See Albert, supro note 31, at 687; Albert, supro note 76, at 255; see also Rezie, supra note 37; Bohdan A. Futev, Comments on the Constitution of Ukraine, 5 E. Eur. Const. Rev. 29, 30 (1996)
} 
requiring strict compliance. ${ }^{79}$ Due to its elasticity and semantic openness, unamendability formulated as a general principle allows balancing and flexibility. As Denis Baranger remarked with reference to the French constitution, "there is nothing objective or merely procedural about such a standard as the 'integrity of the territory." ${ }^{80}$ Therefore, the content of the so-called eternal protection of territorial indivisibility mav evolve and change with time and in a social context; it allows debate, interpretation and reinterpretation of its meaning.

Skeptics would argue that the commitment to territorial integrity is a declaration of principle referring purely to securing the country's external borders and is thus by definition constitutionally unenforceable. In other words, it is akin to a declaration of independence: Mostly declaratory in nature and vulnerable to political reality rendering it meaningless. This line of interpretation is only partially persuasive. First, one might argue that this commitment can be understood as imposing a constitutional duty on the state organs to defend the territorial integrity of the state or struggle for its re-establishment, especially if read together with Article 17, which makes defending the sovereignty and territorial integrity of Ukraine a major state function. ${ }^{81}$

Second, and more importantly, this provision should be read in the context of the entire Ukrainian constitution, especially in conjunction with the strong judicial review powers afforded to the constitutional court. Therefore, as we argue in greater detail in the following section, this eternity clause appears intended to function as more than a nonjusticiable declaration of principle.

Ukraine's provision of unamendability thus needs to be read against the background of the entire constitution, including the role of Ukraine's constitutional court as guardian of the constitution and as protector of the territorial integrity. But before that, the

${ }^{79}$ Dieter Comrad, Basic Structure of the Constitution and Constitutional Principles, in LAW \&. JUSTICE-AN ANTHOLOGV 186, 194 (Soli J. Sorabjee ed., 2003). On the distinction between principles and rules, see Ronald M. Dwarkin, The Model of Rules, 35 U. CHI. L. REv. 14, 25 (1967-1968); RoNALD DworílIN, TAKING RIGHTs SERIOUSLY 24 (1978); Robert Alexy, on the Structure of Legai Principies, 13 Ratio JuRIs 294, 295 (2000).

${ }^{30}$ Denis Baranger, The Language of Eternity: Judicial Review of the Amending Pawer in France (ar the Absence Thereof), 44 ISR. L. REV. 389, 404 (2011).

${ }^{11}$ Compare this with the following: Art. 104 of the constitution of the Republic of Equatarial Guinea (1991), according to which the territorial integrity shall not be subject to reform, in conjunction with Art. 16, according to which "All Equatorial-Guineans shall have the obligation to . . defend [the state's] ... territorial integrity and national unity ... "; the Bu garian constitution (1991), according to Art. 2(2) of which "[t] he territorial integrity of the Republic of Bulgaria shall be imviolable," also recogmizes im the Preamble the "duty to guard the national and state integrity of Bulgaria." See also Theodare Christakis, Self-Determination, Territorial Integrity and Foit Accompli in the Case of Crimea, 75 ZNORV/HeIDELEERI JIL 75 (2015) (arguing that more than eighty constitutions out of the 108 the author reviewed "have wording showing that any unilateral attempt to secede should be deemed anti-constitutional, and some of them even provide for the state to adopt concrete measures to combat secessionist activities"). 
unamendability of territorial integrity must be squared with the possibly contradictory territorial arrangements inscribed in the Ukrainian constitution.

It is not straightforward how Article $157^{\prime}$ s unamendable commitment to indivisibility, to the extent that it was meant as more than declarative, can be squared with the special provisions on Crimea. ${ }^{82}$ Although the latter's status was confirmed as exceptional by all sides during the constitution-making process, ${ }^{83}$ maintaining Ukraine's territorial integrity remained of equal if not higher concern. On the one hand, Article 134 of the constitution declares Crimea "an inseparable constituent part of Ukraine." ${ }^{\text {"84 }}$ Similarly, the hard-fought constitution of the Autonomous Republic of Crimea speaks of the region as "an integral part of Ukraine." ${ }^{\prime 85}$ On the other hand, Article 138(2) lists the organization and conduct of local referendums within the competence of Crimean authorities, while the Crimean constitution declares "sovereignty of the people" as a fundamental principle under article 2(1). ${ }^{86}$ More confounding still is Article $7(2)$ of the Republic's constitution, which states: "The territory of the Autonomous Republic of Crimea may be changed if it should be so resolved by a republican (local) referendum and by a resolution of the Supreme Rada [Council] of the Autonomous Republic of Crimea pursuant to the Constitution of Ukraine.." ${ }^{87}$ The latter's compliance with the constitution of Ukraine was certified by the Constitutional Court of Ukraine in the case on the constitution of the Autonomous Republic of Crimea of 2003. ${ }^{88}$

Thus, the most plausible interpretation of "territorial indivisibility" is compatible with, and respectful of, Crimea's status. In other words, what the drafter plausibly sought to render "eternal" or unamendable was the external territorial status quo at the time of constitutional adoption-the integrity of Ukraine's external boundaries, rather than limit internal territorial reorganization. The Venice Commission seems to support this interpretation: "The state's indivisibility is not to be confused with its unitary character, and therefore consorts with regionalism and federalism." ${ }^{89}$

\footnotetext{
${ }^{n 2}$ The characteristics of state indivisibi ity and unity are strongly linked. See Stéphane Pierré-Caps, Constitutional Non-Recognition of Minorities in the Context of Unitary States: An insurmountable Obstacie? in THE PARTICIPATION or MINORITIES IN PUBuC LITE 11-12 (2011)

${ }^{n}$ See Wolczuk, supra note 19 , at 159.

${ }^{84}$ UKRAYNSKa KonstmUZlYa June 28, 1996, ch. $X$, art. 134 (Ukr.) (emphasis added).

${ }^{35}$ The Constitution or the Autonomous Repuelic or Crime $\wedge$ October 21, 1998, ch. 1, art. 1(1).

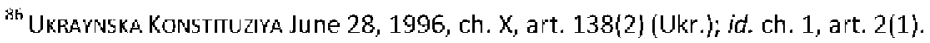

${ }^{87}$ THE CONSTITUTION OF THE AUtONOMOUS Repuelic Of CRIMEA October 21, 1998, ch. 2, art. 7(2).

${ }^{38}$ Dec of the Const. Ct. of Ukraine, No. 01-pp/2003 (Jan. 16, 2003).

"venice Commission, supra note 16 , at 3
} 
Even if that were the case, however, events predating the 2014 Crimean referendum should have already raised the alarm concerning the constitutional text's contradictions. ${ }^{90}$ Notwithstanding the autonomous status of Crimea, the accepted understanding in Ukraine is that Regional Self-Government entities must be "loyal to and in compliance with territorial integrity. ${ }^{21}$ Thus, even though many in Crimea consider Russia as their homeland, "the Ukrainian leadership, while accepting that Crimean Russians were oriented towards Russia, had always drawn the line on any attempt at infringing its territorial integrity." 92 Furthermore, the fear of "separatism, secession, country breakdown and disintegration" shaped Ukraine's constitutional arrangements including its fundamental constitutional principles as reflected in Article 157, and its perception of minority issues. ${ }^{93}$

Ukraine is by no means unique amidst post-communist countries in its sensitive constitutional balancing act: Seeking to build a strong, unitary state while ensuring, sometimes reluctantly, minority accommodation in a multi-ethnic society. ${ }^{94}$ References to territorial integrity abound in post-communist constitutions, alongside declarations of political independence and an embrace of popular sovereignty. ${ }^{95}$ Moreover, the constitutional protection of territorial integrity helps to expose common fears of territorial disintegration and loss of independence. However, where they are accompanied by a constitutional court empowered to enforce such provisions, the unamendability of territorial integrity moves beyond mere proclamation and into constitutional doctrine.

\footnotetext{
so The 1994 Crimean referendum, which proceeded despite being declared illegal by the U/krainian electoral ommission and President, returned positive answers to the questions of whether the region should have greater autonomy, whether its citizens should hold dual Ukrainian-Russian citizenship, and whether the decrees of the Crimean provincial President should have the status of law. See Mark CLARENCE WALkER, ThE STRATEGIC UsE OF RefERENDUN15: POWER, LegTIMACY, AND DEMOCRACY 108 (2003).

91 V. Volkov, Problems of Improving the Constitutional Foundations of Self-Government in Ukraine, 2012 LAW UkR. LEGALJ. 88, 98.

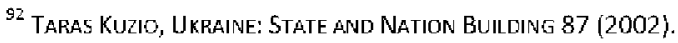

93 Protsyk, supra note 45, at 1-2. See generally Yegor Vasylyev, Legal Transplants in the New Constitutians: Comparative Study of ukraine and Poland, 4 J. EurnsinN L. (2011).

${ }^{94}$ See Culic, supra note 26 , at $44-47$ (providing an overview of post-communist countries having incorporated such const itutional provisions).

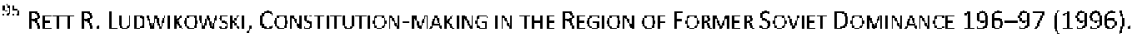




\section{1il. The Constitutional Court as Guardian of the Territory}

Ukraine constitutional system protects human rights and recognizes the practice of judicial review. ${ }^{96}$ The Constitutional Court not only has authority to judicially review ordinary legislation, but can also give judgments on proposed constitutional amendments through $a$ priori judicial review. ${ }^{97}$ According to Article 159 of the Ukrainian constitution, a preliminary opinion of the Constitutional Court regarding the conformity of proposed amendments with the requirements of Articles 157 and 158 of the Constitution-an ex ante review-is an essential stage of the procedure in order for a constitutional amendment to be adopted by the Verkhovna Rada. ${ }^{98}$ In other words, the preventive review by the Constitutional Court on the compatibility of draft amendments to the requirements of Articles 157 and 158 is a prerequisite for the Verkhovna Rada to continue and to adopt the proposed amendments. ${ }^{99}$ Thus, although the Constitutional Court's discretion is limited by the explicit criteria for review as stipulated in the constitution, albeit always with some leeway because these are vague principles, the Constitutional Court is clearly granted a veto role within the amendment process. ${ }^{100}$ Indeed, in several opinions, the Constitutional Court has held that proposed amendments contradict the provision of unamendability and should be revised. $^{101}$

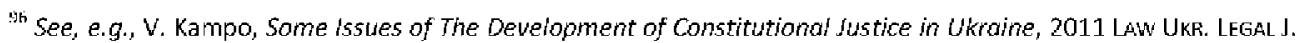
196 (2011); V. Tykhy;, The Legal Noture, Powers, Decisions and Opinions of the Constitutional Court of Ukraine, 2011 LNW UKR. LEGML J. 206, 207-08 (2011); Serhiy Holovaty, Ukraine in Transition: From Newly Emerged Democracy Towards Autocracy?, 26 Rev. Cent. \& E. Eur. L. 267 (2000).

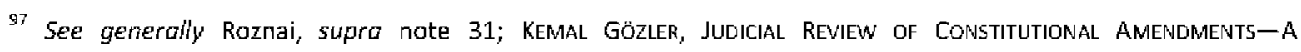
COMPARATIVE STUDY 5-7 (2008).

98 Ukraine Const. (1996), art. 159; Tykhyi, supra note 96, at 207-08 (2011); Gábor Halmal, Perspectives on Global CONSTITUTIONMLISM 40 (2014); WOJIECH SADURSkI, RIGHTS BeroRe COURTS: A StudV or CONSTITUTIONAL COURTS IN Postcommunist States of Central and Eastern Europe 25, n. 116 (2014); see generalfy Futey, supra note 78 (disoussing the Constitutional Court).

See Dec. of the Const. Ct. of Ukraine, No. 13-rp/2008 (June 26, 2008) (regarding the constitutional petition of 4 ) National Deputies of Ukraine concerning the constitutionality of item 3.1, Chapter IV of the Law of Ukraine "On the Constitutional Court of Ukraime"); see also Dec of the Const. Ct. of Ukraine, No. 06-pp/2008 (Apr. 16, 2008) (concernirg a constitutional petition of the President of Ukraine for official interpretation of provisions of Articles $5.2,5.3,69,72.2,74,94.2$ and 156.1 of the Constitution), cited in Yu Barabash, Constitutional Reform and Stability of the Constitutional System: Coflictoiogical-iegal Anolysis of Systemic Interinkage, 2012 LAW LKR. LFGAL J. 116, 131 (2012), http://www.ccu.gov.ua/en/doecatalog/list?currDir=18147 (providing summaries in English).

${ }^{1 \text { in }}$ Oleh Protsylk, Troubled Semi-Presidentialism: Stability of the Constitutional System and cabinet in ukraine, 55 EUROPE-ASIA STULS. 1077, 1089 (2003)

${ }^{101}$ For example, see the Opinion of the Constitutional court of Ukraine, in the case upan the appeal of the Verkhowne Rodo of Ukraine, providing an oainion regarding the constitutionality of introducing amendments to Articles $80,105,126$, and 149 of the Constitution of Ukraine for immunity to requirements of Arts. 157 and 158. Op. of the Const. Ct. of Ukraine, No. 01-v/2012, (July 10, 2012) (finding the abolition of immunity af judges as infringing upon their ability to conduct an independent, objective and fair justice for the purpose protecting human and citizens' rights and freedoms), http://www cougovua/en/doccatalog/list?currDir=182897; see also 
An example of the veto role by the Constitutional Court in the amendment process is its judgment of 30 September 2010. In 2004, the Ukrainian parliament considered an important constitutional amendment that aimed to make substantial changes to the organization of the executive branch. The draft amendment was duly submitted to the Constitutional court, which confirmed its admissibility. ${ }^{102}$ In the course of the parliamentary debates, the original text of the amendment was substantially modified, and the final version was adopted without being resubmitted to the Constitutional Court for its opinion. ${ }^{103}$ Six vears later, 252 People's Deputies filed a constitutional complaint challenging the procedural validity of the 2004 amendment before the Constitutional Court. In its judgment, the Constitutional Court decided that because the amendment was revised and approved by the Verkhovna Rada without the obligatory opinion of the Constitutional Court, it was adopted in a procedural vialation of Article 159 of the constitution; thus it was declared unconstitutional and void. ${ }^{104}$ But that case concerned a procedural review of the adoption of the amendment rather than a substantive review of its content.

Interestingly, the Venice Commission questioned the legality and legitimacy of that decision because the Constitutional Court conducted its review of the amendment after it entered into force and the court only possessed authority to conduct a preliminary review. ${ }^{105}$ However, in an earlier decision in 2008 , the Constitutional Court held that it also

Op. of the Const. Ct. of Ukraine, No. 1-v/2010, (Apr. 1, 2001) (providing an opinion an the constitutianality conformity of amendments to Articles 80, 105, and 108 of the Constitution of Ukraine, concerning guaranteeing immunities to certain officials, with the provisions of arts. 157 and 158 of the Constitution of Ukraine, in which the court found that providing liability exemption of People's Deputies of Ukraine for statements that contain insult or defamation in Parliament and its bodies might violate fundamental rights and freedoms), http://www.ccu.gov.ua/en/doccatalog/list?eurrDir=108166; Kampo, supra note 96, at 196.

102 Op. of the Const. Ct. of Ukraine, No. 03-v/2004, (Dec. 10, 2003); Op. of the Comst. Ct. of ukraime, No. 02v/2004, (Oct. 12, 2004), http://www.ccu.gov.ua/en/doccatalog/list?curr Dir=108166.

${ }^{103}$ See Opinion on the Procedure of Amending the Constitution of Ukroine, Op. of the Eur. Comm'n for Democracy Through Law (Venice Comm $\mathrm{m}$ ), No. 305/2004, para. 25 (Oct. 8-9, 2004), http:/www.venice.coe.int/webforms/documents/default.aspx?pdffile=CDL-AD(2004)030-e (expressirg its concern regarding the disregard for the role of the constitutional court in the amendment process).

${ }^{114}$ See Dec. of the Const. Ct. of Ukraine, No. 20-rp/2010, (Sep. 30, 2010) (concerning the constitutionality of the Law of Ukraine "On Introduring Amendments to the Constitution of Ukraine," No. 2222-IV, (Dec. 8, 2004), http:/www.cou.govua/en/doccatalog/list?currDir=91909; see also Lech Garlicki \& Zofia A. Garlicka, Extema' Review of Constitutional Amendments? international Law as a Norm of Reference, 44 ISR. L. REV. 343, 348, $\mathrm{n}$. 8 (2011).

${ }^{105}$ See Opinion on the Constitutional Situation in Ukraine, Op. of the Eur. Comm'n for Democracy Through Law (Verice Comm'n), No. 599/2010, paras. 31-32 (Dec. 17-18 2010), http:/www.venice.coe.int/webforms/documents/default.aspx?pdffile=CDL-AD\%282010\%29044-e; The venice Commission added, at paragraphs 35-36: "It also considers highly unusual that far-reaching constitutional amendments, including the change of the political system of the country-from a parliamentary system to a 
possessed the competence to exercise ex-post (rather than only ex-ante) constitutional review of amendments to the constitution, even after these are adopted by the Verkhovna Rada. The reasoning was based on the fact that the constitution did not restrict that possibility and in order to adequately protect fundamental rights and freedoms, state independence, and territorial integrity. ${ }^{106}$

In new democracies, constitutional courts often receive a central place as guarantors of the constitution ${ }^{107}$ and even of the democratic integrity in conflicted societies. ${ }^{108}$ The Ukrainian Constitutional court often acts as a mediator between political actors. ${ }^{109}$ it is granted with a rare authority to take part in the constitutional amendment process and to protect the provision of unamendability; most constitutional courts do not explicitly possess such a competence. ${ }^{10}$ Put differently, the Constitutional court is the legal guardian of territorial integrity-among other unamendable principles-and in its opinions on draft amendments it reviews whether draft laws "are oriented toward the liquidation of the independence or violation of the territorial indivisibility of Ukraine." ${ }^{111}$ of course, it

parliamentary-presidential one-are declared unconstitutional by a decision of the Constitutional court after a period of six years. The Commission notes however, that neither the Constitution of Ukraine nor the Law on the Constitutional Court provide for a time-limit for contesting the constitutionality of a law before the CCU. As Constitutional Courts are bound by the Constitution and do not stand above it, such decisions raise important questions of demorratic legitimary and the rule of law." id.

1 in See Dec. of the Const. Ct. of U/craine, No. 13-rp/2008 (June 26, 2008) (regarding the constitutianality of Chapter IV of the Law of Ukraine, "On the Constitutional Court of Ukraine," by the appeal of Forty-Seven People's Deputies of U/raine), htto:/www.ccu.gov.ua/en/doccatalog/list?currDir=18147.

10 Gabor Halmai, Unconstitutionat Constitutional Amendments: Constitutional Courts as Guardians of the Constitution? 19 CONSTELLATIONS 182 (2012); HALMAI, supro note 98, at 40.

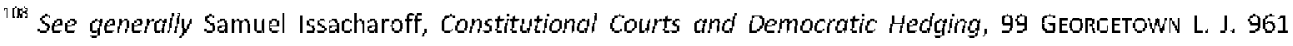
(2011).

109 Trevor L. Brown \& Charles R. Wise, Constitutional Courts and Legisiotive-Executive Relations: The Cose of Ukroine, 119 Pol. Sa. Q. 143, 155 (2004).

${ }^{110}$ of course, in some jurisdictions, courts have taken upon themselves such a judicial role, even without an explicit authority in the constitution. See Yaniv Roznai, unconstitutional Constitutional Amendments-ihe Migration and Success of a Constitutional idea, 61 AM. J. COM. L. 657 (2013); ROzNAI, supra note 31; GözlER, supra note 97 , at $5-7$.

11" The involvement of courts in questions of territory is not in itself unique. See, e.g., Texas v. White, 74 U.S. 700 (1868) (deciding that despite affiliation with the Confederacy during the Civil War, states did not-and cannotunilaterally secede from the United States; this was a celebrated decision of the U.S. Supreme Court). A more contemporary notable example is the Canadian Secession of Quebec case, in which the Supreme Court held that although a majority will of a people to secede, as expressed in a referendum, must be taken into a consideration, there are other important principles such as federalism, minority rights and the rule of law which must be observed. According to the rule of law principle, secession of a province should be carried out according to the Camadian constitutional rules which govern the amendment process. Moreover, the Court uncovered an unwritten duty to negatiate in the event of a formal amendment on secession. See Reference re the Secessian of Quebec, [1998] 2 S.C.R. 217 (Can.), http//scc-csc.lexum.com/decisia-sce-csc/sccosc/sco 
might be questioned how the Constitutional Court can protect the unamendable principle when faced with significant external pressures or with an overly political issue, such as a referendum on the territory. ${ }^{112}$ What is clear is that this "judicial preview" mechanism demonstrates that the unamendability of the territorial indivisibility was intended to be judicially enforceable and not merely declaratory.

\section{Formal Unamendability}

\section{The Functions of Unamendability}

Formal unamendability usually takes place in the form of explicit constitutional provisions that designate certain constitutional subjects-such as principles, rules, institutions, and symbols - as unamendable through the formal constitutional amendment process. There is a growing trend in global constitutionalism to provide for formal unamendability. ${ }^{113}$ The "new" constitutional orders in Central and Eastern Europe following the collapse of communism protect human rights and recognize the practice of judicial review. ${ }^{114}$ Although some have argued that it would be a mistake for these new democracies to import the German "fondness for unamendable provisions" as the vexing questions that they face ought to be resolved in the political sphere rather than in constitutional courts, ${ }^{115}$ many of these states adopted provisions of unamendability. ${ }^{116}$ Among the states that

cc/en/tem/1643/index.do; see also Peter H. Russell, Can the Conadians Be a Sovereign People? The Question Revisited, in Constitutional Poutics in Canada and the United 5tates 9, 22 (Stephen L. Newman ed., 2004); Oklapcic, supra note 15.

\footnotetext{
${ }^{112}$ See, cf., Holovaty, supro note 96 , at 281 ("Where a decision involves a significant issue of executive authority, such as the recent referendum decision, there is a danger of significant external pressure being exerted on the Court to reach a decision [favorable] for the executive."); see MARI POPOVN, POLITICIZED JUSTICE IN EMERCINC DEMOCRACIES: A STUdY OF COURTS IN RUSSIA AND UKRAINE (2012) (providing a comprehensive study of political pressure on judicial independence in $\mathrm{U}$ (craime).

11.3 According to one study, between 1789 and 1944, almost twenty percent of all new constitutions included unamendable provisions, while, between 1945 and 1988, almost thirty percent of new constitutions included such provisions, and between 1989 and 2013, already over fifty percent of new constitutions include formal unamendable provisions. See Roznai, supra note 16 . Unamendability can alsa be implicit and judge-made through judicial decisions; Roznai, supra note 110; RozINA, supra note 31; GozLER, supra nate 97.

${ }^{114}$ Wiktor Osiatynski, Rights in New Constitutions of East Central Europe, 26 Coum. Hum. RT5. L. Rev. 111 (1994);

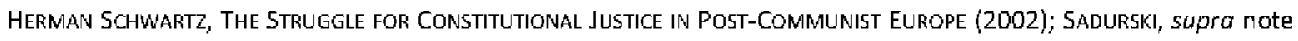
98.

${ }^{115}$ Stephen Holmes, Back to the Drowing Bourd: An Argument for Constitutional Postponement in Easter Europe, 2 E. EUR. CONST. REV, 21, 22 (1993).

${ }^{116}$ See, e.g., CrFch Republic Constitution Dec. 16, 1992, art. 9; Kazakhstan Constitution Aug. 30, 1995, art. 91(2); Moldova CONST. July 29, 1994), art. 142; ROMANIA CONST. Nov. 21, 1991, art. 152(1); LEVENT GONENĢ, PROSPECTS FOR Constitutionalism in Post-Conmunist Couvtries 372 (2002). On constitutional revisions in Eastern Europe, see Stephen Holmes \& Cass R. Sunstein, The Politics of Constitutional Revision in Eastern Europe, in Respondine To IMPERTECTION: THE THEOKY NND PRACTICE or CONSTITUTIONML AMENDMENT 275 (Sanford Levinson ed, 1995); Rett T.
} 
incorporate provisions of unamendability, the Ukrainian case is exceptional in the role it assigns to the judiciary. The only other constitutions empowering the Constitutional Court to adjudicate initiatives for revising the Constitution a piori to any amendment's adoption are Kyrgyzstan, ${ }^{117}$ Kosovo, $^{118}$ and Romania. ${ }^{119}$

Unamendability fulfills various functions. ${ }^{120}$ Preservation of the constitutional order and its constitutive values is a principal aim of provisions on unamendability. Formal unamendability functions as a barrier to change, aiming to afford additional protection to certain principles by blocking the constitutional amendment process and in so doing averting possible alteration of basic constitutive principles and core features of the constitutional identity. Such protected fundamentals are considered by the constitutiondrafts as worthy to last for generations. Unamendability not only points to the importance of the enshrined principle to the constitutional order but also supposedly functions as "a perfect protection against impulsive rashness," 121 reflecting a certain "amendophabia" that the amendment process might be abused in order to repeal societies' basic values. ${ }^{122}$ At the very least, unamendability and its institutional enforcement through judicial review mechanisms may provide additional time for the people to reconsider their support for a change of their core principles, thereby hindering revolutionary movements. ${ }^{123}$ As Gregory

Ludwikowski, Constitutional Cuiture of the New East-Central European Democracies, 29 G . J. INT'L \& COMP. L. 1, $14-21(2000-2001)$.

${ }^{117}$ See Kyrgyzston, 28 The World of ParlaAments-Quarterly RevieW of the INTER-Parlamentary Union 15 (2007) (looking at the constitutional court in Kyrgyzstan where, on 14 September 2007, and without explicit authority, the court annulled and changed two constitutional amendments on formal grounds, and in 2011 a constitutional amendment endowed the constitutional court with an authority to provide its opinion during a preliminary review of constitutional amendments).

${ }^{113}$ See THE REP. or Kosovo CONSt. Jume 15, 2008, arts. 113(9) and 144(3) (explicitly granting the Court authority of an a priori review of aroposed amendments and to examine whether proposed amendments diminish rights and freedoms guaranteed by Chapter II of the Constitution. If the Court declared any proposed amendment as "uncanstitutional," the Assembly cannot vote on it). See Enver Hasani, Preventive Abstract Controi of Constitutional Amendments and Pratection of The Head of State From Unconstitutional Dismissol: The Case of Kosovo, 1 E DREJTA-LAW REVISTE fër ÇÉSHTJE JURICIKE DHE SHOQËRORR 105, 106 n. 188 (2003); Enver Hasani, Constitutional Protection of the Head of 5tate; The Case of Kosovo, 7 VIENNA J. INT'L CONST. L. 128 (2013).

${ }^{11}$ See Romania CONST. Nov. 21, 1991, art. 146(a); Ion Deleanu \& Emil Boc, The Control of the Constitutionality of Laws in Romania, 2 J. Const. L. E. \& CENT. Eur. 119, 120, 124 (1995); loan Deleanu, Separation of PowersConstitutional Regulation and Practice of the Constitutional Court, 3 J. Const. L. E. \& CENT. EuR. 57, 63 (1996); Nicole Popa, The Constitutional Court of Romania, Twelve Years of Activity: 1992-2004, Evolutions Over the Last Three Yeors, CONST. CT. BLLLETIN, https://WwW.ccr.ro/Nr-7-2004 (last visited June 16, 2015).

${ }^{120}$ Albert, supra note 3178 ; Roznai, supra note 16.

121 Jon Elster, Majority Ruje and Individual Rights, in The Politics of Human Rights 120, 146 n. 35 (Obrad Savić ed., 2002).

${ }^{122}$ Roznai, supra mote 16.

$12 i$ Bruce Ackerman, We the Peorle: Foundations 20-21 (1993). 
Fox and Georg Nolte remark with reference to the German provision of unamendability, ${ }^{124}$ the framers of the German Basic Law believed that if a provision of unamendability "had been presented in the Weimar constitution, Hitler would have been forced to violate the constitution openly before assuming virtually dictatorial power. . . . [G]iven the traditional orderly and legalistic sentiment of the German people, this might have made the difference." ${ }^{125}$

Unamendability can also have a transformative function, contrary to its preservative one. This is the case when unamendability seeks to repudiate the past and guide the nation to a new path by providing it a fresh constitutional identity for a better future. It "endeavors to repudiate the past by setting the state on a new course and cementing that new vision into the character of the state and its people. ${ }^{126}$ Unamendability provisions not only reflect a constitutional commitment to certain enshrined principles but "promise a brighter future... [and] imagine a more perfect polity, the kind that the citizenry aspires to become and preserve." ${ }^{127}$ As the principles which are protected by this prospective unamendability might be at variance with the historical or prevailing social and cultural conceptions, system of values, or conditions, ${ }^{128}$ this unamendability is often merely aspirational.

Whether unamendability is aspirational or a justiciable legal commitment, and regardless of the preservative or transformative functions of unamendability, there is one characteristic shared by these types of unamendability, which is their expressive value. Jon Elster notes that "the purpose of . . unamendable clauses is . . mainly symbolic." ${ }^{129}$ Even if not judicially enforceable, or regarded as merely declaratory, unamendability creates the appearance of respect for the protected principle or institution and "makes a statement" regarding its importance to the constitutional order. ${ }^{130}$ By designating certain principles as unalterable, unamendability expresses the relative significance of the unamendable

\footnotetext{
${ }^{124}$ See Helmut Goerlich, Concept of Special Protection For Certain Elements and Principles of the Constitution Against Amendments and Article 79(3), Basic Law of Gernary, 1 NUJ5 L. REV. 397, 397 (2008) (discussing how Art. 79[3) of the Basic Law of the Fed. Rep. of Germany prohibits amendments affecting the division of the federation into states, human dignity, the constitutional arder, or basic institutional principles describing Germany as a democratic and social federal state).

${ }^{12 \mathrm{~h}}$ Gregory H. Fox \& Georg No te, intolerant Democracies, 36 HARV. INT'L L. J. 1, 19 (1995).

136 Albert, supra note 31 , at 685 .

${ }^{127}$ ROZNAl, supro note 31 , at 40 .

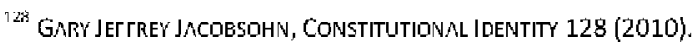

139 Jon Elster, Constitutionalism in Eastern Europe: An Introduction, 58 U. CHI. L. Rev. 447, 471 (1991).

${ }^{130}$ See Cass R. Sunstein, On the Expressive Function of Law, 144 U. PA. L. REV. 2021, 2024-25 (1995-1996) (discussing the function of law in "making statements").
} 
principles to the constitutional order compared to the other amendable principles. The unamendability of a principle or an institution sends a message to both internal and external observers regarding the state's basic constitutional principles thereby conveying its symbolic value. ${ }^{131}$ As Richard Albert notes, formal unamendability "is the ultimate expression of importance that can be communicated by the constitutional text." ${ }^{132}$ Therefore, unamendability carries an important symbolic, expressive, and educational function.

Finally, unamendability can fulfill a certain deliberative task. At first glance it appears that by blocking mechanisms for modifying certain principles or rules, unamendability takes away citizens' ability to participate in debates regarding society's basic values, thereby risking impoverishing democratic debates. However, unamendability can actually force deliberation, hopefully public, before action is taken to either attempt to circumvent or ignore the unamendability. In other words, the declaration of unamendability remains important-even if conceived as eventually amendable or with a limited effect-because its removal still necessitates political and public deliberations regarding the protected constitutional values. True, it cannot serve as a complete bar against movements aiming to abolish unamendable principles, rules, or institutions. ${ }^{133}$ Nevertheless, it is not completely unusable because it has a "chilling effect,"leading to hesitation before repealing it and may trigger political deliberation as to whether the amendment in question is compatible with society's basic principles. ${ }^{134}$

\footnotetext{
${ }^{131}$ Elster, supra note 129, at 471; Albert, supra nate 31, at 699-702; see Albert, supra note 76 (discussing the expressive function of amendment provisions).

${ }^{1.32}$ Richard Albert, The Unamendabie Core of the United States Constitution, in COMParattve PerspeCtives on the Fundamental Freedom of Expression (András Kaltay ed., 2016) (forthcoming, on file with authar), http://ssm.com/abstract=2601646.

${ }^{133}$ Dietrich Conrad, Limitation of Amendment Procedures and the Constituent Power, 15-16 INDIAN Y.B. INT'L. AfF. 380,394 (1970).

${ }^{1.34}$ Jason Mazzone, Unomendments, 90 lowa. L. Rev. 1747, 1818 (2005).
} 


\section{The Formal Unamendability of Territorial Integrity}

The concept of territorial indivisibility was originally established as a monarchic principle of inheritance and succession to avoid division of the country among the monarch's heirs. ${ }^{135}$ Interestingly, one of the earliest examples of unamendability of territorial integrity is related to the transition of Albania from republic to monarchy. The 1928 Fundamental Statute of the Kingdom of Albania expressly prohibited revisions to the inheritance of the throne; to the capital; to the characteristics of Albania as a democratic, parliamentary, and hereditary monarchy; and to its status as an independent and indivisible state. Albania's territorial integrity was inviolable and its land inalienable. ${ }^{136}$

Current views on territorial integrity find that it is connected to the state's sovereignty and "right to exist."137 From a constitutional theory point of view, territory is one of the elements that make a state and is an important element of state authority. ${ }^{138}$ Because every polity wants to preserve its own existence and identity, it appears prima facie clear why a state would want to protect its territorial integrity, alongside other core constitutional and democratic commitments, from possible incursions through amendments. For "substantive democracies" tolerance finds its limits "when its core values are at stake." "I39 Indeed, "even a tolerant democratic society must be able to police its fragile borders." ${ }^{140}$ States are therefore reluctant to legitimize secessionist claims because they have a general interest in preserving their own territorial integrity. ${ }^{141}$ The will of self-preservation and the fear of a country's breakdown or disintegration are often reflected in the constitutional unamendability of territorial integrity or indivisibility.

\footnotetext{
${ }^{135}$ Joseph Marko, United in Diversity?: Problems of State-and Nation-Building in Post-Conflict Situations: The Case of Bosnia-Herzegovina, 30 V. L. REv. 503, 505 (2005-2006); Joseph Marko, Ethnopolitics. The Chalienge for Humon and Minority Rights Protection, in PhILOsophical DIMENSIONs of HUMAN RIGHTS: SOME CONTEMPORaRY VIEWs 265, 266 (Claudio Corradetti ed., 2012).

${ }^{136}$ The Fundamental Statute of THe Kingdom of AlBania (1928), art. 224(2); see Lavdosh Ahmetaj, The Transition of Albania from Repubilc to Monarchy, 10 EUR. SCI. J. 208 (2014), http://eujournal.org/index.php/esj/article/viewFile/4578/4375 (providing a chronological description of the transition from republic to manarchy). See generally Makbule Çeço, institute of Constitutional Revision in the Constitution of the Repubiic of Aibania, Comparative View, 10 ACADENIICU5-INT'L. Sa. J. 126 (2014), http:/oaji.net/articles/2015/1624-1422980065.pdf /describing the constitutional amendment process in Albaria).

137 abdelhamid El Oual, Territorial Integrity in a Globalzing World: International law and Statej' Quest for SURVIVAL 5-45 (2012).

1:S Nick W. Bareer, The Constitunonal State 22-24 (2010).

139 Angela K. Bourne, The Proscription of Political Parties and Militant Demacracy, 7 J. CoMP. L. 196, 199 (2012).

${ }^{140}$ Samuel Issacharaff, Fragile Democracies, $120 \mathrm{HAFV}$. L. REV. 1405, 1466 (2006-2007).

${ }^{141}$ Chase, supro note 12 , at 232-33.
} 
Indeed, many states include within their constitution protection from amendments which might affect or violate the principle of "integrity and the unity of the national territory" in one term or another. These are mainly African ${ }^{142}$ and Eastern European states, ${ }^{143}$ with some Latin America ${ }^{144}$ and West European exceptions. ${ }^{145}$ All of these national constitutions expressly protect the inviolability of existing territorial borders and reject the possibility of their change, even through the formal rules prescribing constitutional amendments. ${ }^{146}$ Given the centrality of the principle of territorial integrity in international law, it is not surprising that countries engaged in state-building processes would seek to incorporate it into their basic laws. Territorial integrity also takes center-stage in bilateral border agreements between post-communist states and their neighbors. ${ }^{147}$ This list shows that such unamendability commonly appears in constitutions of many states that were former colonial territories or formerly under foreign rule. In its external perspective which regards interactions with other sovereigns, the unamendability of territorial integrity serves as a

\footnotetext{
${ }^{142}$ See, e.g., Constmution of Algeria February 23, 1989, arts. 178(2); id. Nov. 19, 1976, 195(5); Constitution of ANCOLA Nov. 11, 1975, art. 159(a); id. Jan. 21, 2010, art. 236(b); CONSTITUTION Or THE REPUBLIC Dr BENIN CONST. Dec. 2 , 1990, art. 156; CONSTITUTION OF BuRkina Faso June 14, 1970, art. 106; id. June 2, 1991, art. 165; BuRUNDI Constitution, Rererendum March 9, 1992, art. 182; id. Feb 28, 2005, art. 299; Constitution or the Republic or CAmeroon June 2, 1972, art. 63; $i$. Oct. 1, 1961, art. 47; The Constitution of the Repubil of CAPE Verde Sest. 4, 1992, art. 313; Constrtution or CHn Apr. 14, 1996, art. 223; id. Apr. 16, 1962, art. 75; id. Nov. 28, 1960, art. 68; Comoros Constitution Dec. 23, 2001, art. 42; The Republic of Congo Constitutional Referendum Mar. 15, 1992, art.

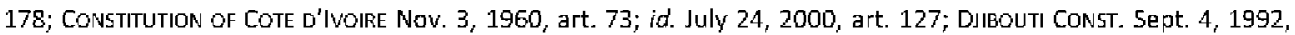
art. 88; EQUATORIML GUinen ConstitLtional Rererendum Nov. 16, 1991, art. 104; id. Aug. 15, 1982, art. 134; id. July 29, 1973, art. 157; CONSTITUTION OF GABON Feb. 21, 1961, art. 70; CONSTITUTION OF GuINEA-Bissau May 16, 1984, art.

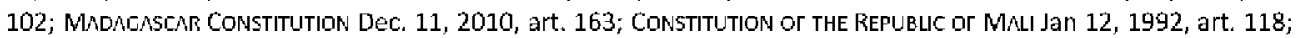
id. June 2, 1974), art. 73; id. Sept. 22, 1960, art. 49; ConsitTution of MaURITANIA July 12, 1991, art. 99(3); id. May 20, 1961, art. 54; CONSTItUTION or NIGER Nov. 8, 1960, art. 73; CONSTITUtION or the Republic or RWANDA May 30, 1991, art. $96(2)$; id. Dec 20, 1978, art. 91; id. Nov. 24, 1962, art. 107; CONSTITUTION OF SAO TOME AND Principe Nov. 5 , 1975, art. 154; Constitution of SonlaAa Aug. 25, 1979, art. 112(3); Togolese Constitutional Referendum Dec. 30, 1979 , art. 53; id. May 5, 1963, art. 85.

${ }^{143}$ Constitution of Azerbaluan Nov. 12, 1995, art. 158; Kazakhstan Constitution Aug. 30, 1995, art. 91(2); Moldova Const. July 29, 1994), art. 142; ROMANIN CONST. Nov. 21, 1991, art. 152(1); TNIKISTAN CONSTITUTION Nov. 30, 1994, art. 100; TIMOR-LesTE (EAST TIMOR) CONSTITUTION May 20, 2002, art. 156; Entela Hoxhaj \& Florian Bjanku, The Basic Principles as Limits of Constitutional Revision in the Constitutional Jurisprudence and Doctrine in Europe, 1 G.J.A.H.S.S. 47, 49-50 (2013).

144 El Salvador Constitution Dee. 15, 1983, art. 248; Honduras Constitution Jan. 20, 1982, art. 374.

${ }^{145}$ CONStitution or Portuigh Apr. 25, 1976, art. 288; Constitution or Turkey Nov. 7, 1982, arts. 3 and 4.

${ }^{145}$ Albert, supra note 31 , at 681.

${ }^{147}$ See Budapest Memorandums on Security Assuronces, 1994, Council on Foreign Relations (Dec. 5, 1994), http://www.cfrorg/nonproliferation-arms-control-and-disarmament/budapest-memorandums-securityassurances-1994/p32484 (discussing how, in Ukraine's case, the Budapest Memarandums on Security Assurances included assurances against "the threat or use of force against the territorial integrity or political independence of Ukraine" by either Russia, the United States, or the UK). This deal was struck in arder to facilitate Ukraine's transfer of nuclear weapons on its territory to Russia and its ratification of the Nuclear Nonproliferation Treaty; it also included assurances to Belarus and Kazakhstan. Id.
} 
means to claim independence and sovereignty. ${ }^{148}$ In its internal, in-country perspective, the unamendability of territorial integrity expresses the state's prioritization of national integrity over any self-determination claims which may arise. ${ }^{149}$ The principle of territorial integrity does not necessarily derive from any constitutive principle of the physical existence of the state. In other words, a state can give up part of its territory thereby violating its territorial integrity and still continue to exist. ${ }^{150}$ Both Egypt and Israel continued to exist without the Sinai Peninsula just as the United Kingdom would continue to exist without Scotland; Canada would continue to exist without Quebec, and so on. ${ }^{151}$ The question may thus be not one of physical existence but of identity:

The relationship between a country's territory and its identity is in many ways similar to the relationship between an individual['s] identity and his or her body. Our individual or collective selves are not the same as the bodies or territories we inhabit, yet there is a clear and undeniable connection between the two. There cannot be persons without bodies and no states without territory. ${ }^{152}$

\footnotetext{
${ }^{143}$ See cf., Charles H. Norchi, The Legal Architecture of Nation-Buiding: An introduction, 60 ME. L. Rev. 281, 287 (2008) (discussing how this happens often as a transformative reaction to a prior challenged territorial integrity).

14. Burak Cop \& Doğan Eymirlioğlu, The Right of Self-Determination in International Law Toward the 40th Anniversary of the Adoption of ICCPR and ICESCR, X PERCEPTION5-J. INT'L AFF. 115, 124 (2005), http://sam.govtr/wp-content/uploads/2012/02/BurakCopAndDoganEymirlioglu.pdf.

${ }^{1.511}$ WEINTAL, supra note 31 , ch. 1.

${ }^{151}$ See Paul R. Williams, Abigail J, Avoryie \& Carlie J. Armstrong, Eorned Sovereignty Revisited: Creating a Strategic Fromework for Managing Self-Determination Based Conflicts, 21 ILSA J. INT'L \& COMP. L. 1, 2 (2015) (noting that "in the last twenty-five years nearly three-dozen new states have emerged. Some new states have arisen from the dissalution of states, while others have seceded from states which then continue to exist ...").

1.52 Erik Ringmar, Russia: Territory and identity Crises (Review Article), 2 Na.TIONS \& Na.TIONALISM 453 (1996).
} 
But as Nick Barber notes, a state can accommodate some change in its territorial features-as well as in other elements such as its members, institution, and rules - without losing its identity. ${ }^{153}$ It is all a matter of the extent and pace of the change. The question is therefore: Would the state remain the same without the territory which was separated? If that answer is no, it might be claimed that if one of the basic rationales behind provisions of unamendability is to preserve a constitutional identity, ${ }^{154}$ then protecting the territorial integrity from amendments makes perfect sense. In the next section we analyze what the Crimean crisis can teach us about using unamendability in order to protect territorial integrity, and expose our principal objection to this mechanism in the area of territorial conflicts.

\section{Unamendability and Territorial Conflicts: Lessons from Crimea}

\section{Unamendability of Territorial integrity and Popular Sovereignty}

The unamendability of the state's territorial integrity may be justified by a republican commitment to achieving the idea of popular self-government. ${ }^{155}$ If certain preconditions such as equality of voting rights must be in place in order for a people to express itself, then these preconditions must be entrenched. Arguably, given the link between popular sovereignty and territory, territorial integrity is one such precondition. However, the Ukrainian experience demonstrates that the unamendability of territorial indivisibility is not required by popular constitutionalism and in fact might be in clear tension with popular sovereignty.

\footnotetext{
15: BerREER, supra note 138, at 141-42.

${ }^{154}$ See Ulrich K. Preuss, The Implicotions of "Eternity Clauses: The German Experience, 44 ISR. L. REV. 429, 445 (2011) ('[Unamendable provisions] define the collective 'self' of the polity-the 'we the people.' If the 'eternal' normative stipulations were changed, the collective self-or identity-of the polity as embodied in the constitution would collapse.").

1.h. Pihut Petiti, On the Peoplés Ternis: A Republican Theory and Model of Democracy (2012).
} 
Ukraine's constitution includes several mechanisms for the expression of popular will. Article 5 incorporates a general commitment to republicanism and popular sovereignty, stating that "[ $t]$ he people are the bearers of sovereignty and the only source of power in Ukraine," while Article 69 lists elections, referendums, and "other forms of direct democracy" as means for the expression of popular will. Hence, the people can exercise their power by the free expression of their will expressly through binding referendums. ${ }^{156}$ Admittedly, Ukraine's experience with direct democracy has not always been praise-worthy. The 2000 national referendum on increased presidential powers and the introduction of an upper house of parliament, for instance, was criticized as a power struggle between president and parliament ${ }^{157}$ and as an exploitation of the referendum for anti-democratic purposes. ${ }^{158}$ What is important for our analysis is that Article 73 of Ukraine's constitution explicitly links popular sovereignty to the notion of territory.

According to Article 73, "[i]ssues of altering the territory of Ukraine are resolved exclusively by an all-Ukrainian referendum," while Article 85(2) indicates it is the Ukrainian Verkhovna Rada which can "designat[e] an all-ukrainian referendum on issues determined by Article 73 of this Constitution." 159 The idea that no territorial change can take place without consent of "the people" finds its origins in the people's attachment to and identification with their territory and in the idea of popular sovereignty according to which the people are the true holders of sovereignty over their territory ${ }^{160}$ Based upon Article 73 , it seems clear that a local referendum could not resolve the issue of Crimea and Ukraine's territorial integrity. ${ }^{161}$

\footnotetext{
${ }^{156}$ CONSTItLTION OF UKRANe June 28, 1996, arts. 5; 69; Tykhyi, supra note 96, at 208-09.

15' András Sajó, Becoming "Europeans": The Impact of EU "Constitutionalism" on Post-Communist Pre-Modernity, in SpReading Democracy and the Rule of Law?: The Impact of EU EnLaRgement on the Rule of Law, Democracy and Constitutionalism In Post-Communist Leg, Orders 180 (Wojciech Sadurskí, Adam Czarnota \& Martin Krygier eds., 2006).

${ }^{158}$ Ronald J. Hill \& Stephen White, Referendums in Russia, the Former Soviet Union and Eastern Europe, in Referendum5 Around the Worid: The Continued Growth of Difect Democracy 35 (Matt Qvortrup ed., 2014).

159 Constitution of Ukraine June 28, 1996, arts. 73, 85(2). The Law on National Referendum of 2012 lists the different referendum types and categories those purporting to change the territory of ukraine as "ratification referendums" (article 3). Article 20 of the law prohibits referendums on territorial changes brought about by popular initiative and reiterates the ban an modifications of the constitution's rights protections, Ukraine's independence and its territorial integrity.

${ }^{100}$ EL OUALI, supra note 137, at 118 . This conceptual relationship between territorial indivisibility and national or popular sovereignty of course begs the preliminary demarcation of "a people" that is declared as "sovereign." See, e.g., Sofia Näsström, The Legitimacy of the Peopie, 35 Political Theorr 624 (2007); see aiso Tierney, supra note 17 (discussing the fraught interaction between self-determination and territorial integrity).

${ }^{16}$ Bilych et al., supra note 2, at 21. One might argue that this is a case where the factual, manifested in a clear and unequivoral majority vote in favor of separation, may well attain its own normative value; in Jellinek's terms:

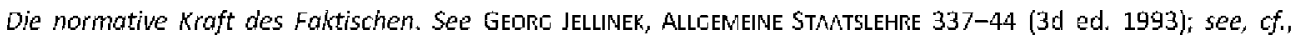


From the point of view of constitutional theory, as Stephen Tierney has explored in his contribution to this volume, the question raised by the Crimean crisis is whether, despite being illegal, its 2014 referendum can plausibly be seen as legitimate. ${ }^{16 z}$ If we ascribe even partial legitimacy to the 2014 independence referendum in Crimea, it demonstrates what Stephen Tiernev has previously argued, namely:

$[T]$ he danger of using referendums in deeply divided societies where they can serve to expose and indeed inflame what is often a dormant disjuncture between the boundaries of territorial government and the nature of the demos/demoi within that territory. ${ }^{163}$

While classifying Ukraine as a "deeply divided society" post-independence may be an exaggeration, ${ }^{164}$ the inflammation of its ethno-linguistic divides have exposed the vulnerability of the country's incomplete internal state- and nation-building processes. Recent events have illustrated the dangers of assuming the "territorial boundaries of the demos . . to to belf-evident." 165 Conversely, if Crimea's 2014 independence referendum is viewed as nothing more than a forceful annexation- "a seizure of territory under threat of force, i.e. as an unlawful annexation ${ }^{165}$-the territorial boundaries of the state are revealed as never having been secure in the first place. Such vulnerabilities are obscured by the categorical language of Ukraine's eternity clause and expose the contents of the clause as more aspirational than preservative.

EdWard MCWhinner, Contitution-MAking: Principles, Process, Practice 40 (1981). On the "Normative Powe of the Factual," see Martin Loughlin, Foundations of Puelic Law 218 (2010); Tierney, supra note 17.

${ }^{162}$ Tieney, supra note 17.

${ }^{163}$ Stephen Tierney, Constitutional Rererendums; The Theory an d PrActice or Repuelican deliberhtion 75 (2012).

${ }^{1 \text { hit }}$ See Pau/S. Pirie, Nationai Identity and Politics in Southern and Eastern Ukraine, 48 EuR.-AsIA STUD5. $1079-104$ (1996) (exploring the complexities of identities in Ukraine); see also Sasse, supra note 44, at 70 (discussing how some have evem argued against oversimplifying the issue of regional diversity in Ukraine, claiming it served as "a key to Ukraine's political stability" during its state-building process).

${ }^{165}$ TIENNEY, supra note 163 , at 59.

7 hitif Peters, supra note 4. 
The main question for our purposes is how this commitment to popular sovereignty corresponds with the provision of unamendability protecting the territorial integrity. A commentator on the Ukrainian crisis has suggested that in order to avoid bloodshed, Ukraine should reform its borders through a referendum: "Let the people decide. If eastern Ukraine really has an affinity for Russia, then let it become a part of Russia. ${ }^{167}$ Because the Ukrainian constitution defines Crimea as an inseparable constituent part of Ukraine, ${ }^{168}$ and provides that "[t]he territory of Ukraine within its present border is indivisible and inviolable", ${ }^{169}$ any secession of Crimea necessitates amending the constitution through a national referendum. ${ }^{170}$ Such an act would still problematically be prohibited by the provision of unamendability. ${ }^{171}$ Therefore, Ukraine's provision of unamendability, which protects territorial integrity from violation by reforms and is enforceable by the Constitutional Court, prevents any secession by referenda. ${ }^{172}$

There are two possible solutions to solve this enigma, neither of which is satisfactory. One solution would be the adoption of a new constitution unbound by provisions of unamendability through a whole new constituent process. ${ }^{173}$ Such an action might be considered a constitutional violation and thus unconstitutional under the current constitution, but its authoritative legitimacy could be granted ex-post facto ${ }^{174}$ Thus, as Stephen Tierney has discussed in this volume, "popular" legitimacy would again be relied upon to overcome a crisis in legality. ${ }^{175}$ A second solution, and a legal one, would be amending the amendment provision itself, through a national referendum as allowed by the constitution, in order to amend Article 157 and remove the unamendability of the territorial indivisibility; then, in the second stage, deciding through a national referendum on the possible division of the territory. This solution would be possible because Article 157, like most provisions of unamendability, is not self-entrenched and could thus be "amended out" of the constitution through a "double-amendment process." Such an act would be legal from a formalistic perspective, although its legitimacy would be questionable as it may be regarded as a "fraud upon the constitution."176

${ }^{107}$ R. Laurem Johnson, A Plan for ukraine, VALLEY NEws (May 9, 2014), http://www.vnews.com/opinion/1189174695/letter-a-plan-for-ukraine (last visited June 16, 2015).

${ }^{168}$ CONSTITUTION OF LKRAINE June 28, 1996, art. 134.

${ }^{1 \text { ind }^{2}}$ ld. art. 2.

${ }^{170}$ As required by the Constitution. /d. art. 156.

${ }^{171}$ Peters, supra note 4.

${ }_{1 / 2}$ Andrew Cybruch, Ukraine's Sovereignty and Territorial integrity are Settled, VNLLEY News (May 23, 2014), http://www.vnews.com/home/11999951-95/letter-ukraines-5overeignty-and-territorial-integrity-are-settled llast visited June 16, 2015).

17.3 See RożAal, supra note 31. Of course, overcoming unamendability by beginning a whole new constitutionmaking process increases the costs as it opens the entire constitution for re-negotiation and accordingly facilitates strateg ic bargaiming. See Stepham Michel and Ignacio N. Cofone, Credible Commitment or Paternalism? The Case 
The dilemma can be manifested through the following hypothetical scenario, an urlikely possibility in Crimea as Ukraine would most likely not agree to secession: We can imagine that the people of an autonomous region wish to secede, as manifested by a genuine local referendum. We can further suppose that such secession is debated within the political bodies which then proceed with a constitutional process for amending the constitution accordingly. Finally, through a national referendum, which is the appropriate procedure for deciding alterations to the territory of Ukraine according to Article 73, "the people" approve such an amendment. The sovereign people, the ultimate holders of constituent power, would thereby choose to alter the unalterable constitution passed in their name. This secession, ratified by a constitutionally permissible national referendum, would still violate Ukraine's unamendable provisions and is thus impermissible, as the people themselves are bound by the unamendability. ${ }^{177}$ By barring constitutional reform which assails territorial integrity, unamendability attempts to place the state's territory not only beyond ordinary politics, but also "beyond the popular will." 178 Hence, it is in clear tension with popular sovereignty.

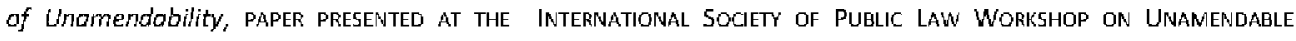
Constitutional Provisions (Koç University Law School, 9 June 2015) (on file with authors).

${ }^{174} \mathrm{Cf}$., Andreas Kalywas, Popular Sovereignty, Democracy, and the Constituent Power, 12 Constellations 223, 231 (2005).

${ }^{1 / 2}$ Tierney, supra note 17.

${ }^{176}$ Richard Albert, Constructive Unamendability in Canada and the United States, 67 S.C.L.R. 181, 209-15 (2014); Yaniv Roznai, Amending 'Unamendable' Provisions, CONSTITUtION-MAkine \& ConstitutionAl CHANGe Bloc lOct. 20 , 2014), http:/constitutional-change.com/amending-unamendable-provisions/ (last visited June 16, 2015).

${ }^{177}$ See generally The Paradox or Constitutionalism: Constituent POWer and Constitutional form (Martin Loughlin \& Neil Walker eds., 2007) (discussing the paradoxes of the constitutional order and constituent power); The Paradox of Constitutiondism: Constituent Power and Constitutional Form, 6 INT'L J. CoNST. L. 358 (Martin Loughlin \& Neil Walker eds, 2008), http://icon.oxfordjournals.org/content/6/2/358.full.pdf (reviewed by Zoran Oklopcic).

1 w John MeGarry, Brendan O'Leary \& Richard Simeon, Integration or Accommodation? The Enduring Debate in Conflict Regulation, in CONSTITUTIONAL DESIGN for DIVIDEd SOCIETIES: InTEGRATION OR ACCOMMODATION? 41, 48 (Sujit Choudhry ed., 2008). 
Ofter, that is precisely the role of unamendability. Unamendability, as a countermajoritarian institution, aims to neutralize the dangers of majoritarianism. ${ }^{179}$ It reflects the idea that certain principles, such as fundamental rights, rule of law, and the democratic principle itself are not subject to the will of the majority, which might abuse them. ${ }^{180} \mathrm{By}$ that, unamendability serves not only to prevent abuse by leaders, ${ }^{181}$ but to serve as a pre-commitment mechanism of "the people" to protect itself against its own weaknesses and passions. ${ }^{182}$ These rationales do not apply to territorial integrity-at least not to a same extent. Thus, the people should be allowed to make this constitutional change dealing with the territory. As long as concern for minority rights is taken into consideration when dealing with negotiations in a context of secession, as Canada's Supreme Court emphasized in its Secession Reference case, ${ }^{183}$ allowing the people to amend their constitution after political deliberation and approval through a national referendum would still maintain a high bar for that constitutional change while simultaneously satisfying the ideals of republican constitutionalism. ${ }^{184}$

${ }^{179}$ Albert, supro note 31 , at 675 .

${ }^{180}$ See, e.g., Gunnar Beck, The Idea of Human Rights Between Value Pluralism and Conceptual Vagueness, 25 PENM St. Int'L L. Rev. 615 (2006-2007); Arnold Brecht, Feceralism and Regionalism in Germany: The Division do Prij5ia 138 (1945).

${ }^{1 * 1}$ Charles M. Fombad, Limits on the Power to Amend Constitutions: Recent Trends in Africa and Their Potentiol impact on Constitutionalism, 6 UNIv. BoTs. L. J. 27, 57 (2007).

${ }^{182}$ STEPHEN HOLMES, PNSSIONS AND CONSTRANNT: ON THE THEOFr Or LIBERML DeMOCRMCY 135 (1995).

1\%: See Reference re Secession of Quebec, [1998] 2 5.C.R. 217, paras. 48-54, 79-82, 90,93 (Can.); see aiso Oklopcic, supra nate 15; Tierney, supra nate 17. But see David HaUAN, Constitutionalising SeCEssion 325 (2014) (questioning how the Supreme court's reference to minority pratection functions alongside the other three principles it put forth for negotiating secession).

184 ILKER GOKHAN ȘEN, SOVEREIGNTY RETERE NDUMS IN INTERNATIONAL AND CONSTITUTIONAL LAW 142 (2015) ("[R] eferendums may fulfill an effective veto function whenever there is a threat to territorial integrity. Thus, a constitutional requirement for the consent of the majority as a condition for a territorial modification may be portrayed as a wise safeguard in the face of political realities."]. 


\section{The Limited Effectiveness and Risks of Unamendability of Territorial Integrity}

A major lesson from the crisis in Crimea is the limited effectiveness of attempts to settle territorial conflicts through unamendability. The unamendability of the territorial integrity principle within the Ukrainian constitution may be regarded as a mechanism aimed at preserving this principle by adding another layer of constitutional illegality to cover situations such as Crimea's. It was meant to be preservative rather than merely declarative, and its intended function is evident from judicial enforcement of unamendability by the Constitutional Court. Nonetheless, while the unamendability provision provided a legal peg on which to hang arguments against territorial change, neither Crimea nor Russia seemed particularly deterred in their course of action by threats. of either constitutional or international illegality. ${ }^{185}$ Furthermore, as noted earlier, Ukraine's constitution already contained mechanisms that were arguably stronger encouraging national deliberation in the eventuality of redrawing the territorial map, not the least of which were national referendums. The recourse to unamendability was meant as an added safeguard but turned out to be no match for forces from both within and without.

The unamendability of the territorial integrity, which must be read in the context of the country's complicated state- and nation-building post-independence process, ${ }^{186}$ also carried an aspirational aspect. Kiev used unamendability to deal with a complex territorial challenge and to entrench its long-term hold on Crimea. The provision of unamendability expressed an aspiration for the resolution of this challenge-the full integration of Crimea within the Ukrainian state-more than an uncontested reality. As this article discussed previously, the problem with aspirational unamendability is that its characteristics might be at adds with the prevailing culture or circumstances of the society. ${ }^{187}$ Territorial indivisibility was incorporated as aspirational in the national constitution, but many of the region's citizens may never have wanted to be part of Ukraine at all. The unamendability, which started out as a constitutional provision with preservative and aspirational functions, could end up being aspirational and nothing more.

\footnotetext{
${ }^{1 \text { th }}$ Of course, from this lack of deterrence one should not infer conclusions regarding the legality of the act. See Christakis, supro note 81

[N]o self-respecting legal order can remain indifferent to the events that have marked Russia's annexation of Crimea. Failure to react would send the message that 'might makes right' and would harm international relations because powerful states might henceforth be tempted to use force against their neighbors to provake 'blitz secessions' and anmex ethmic, linguistic, or religious 'sister' minorities who dream of becoming part of the 'motherland.'

${ }^{186}$ SASSE, supra note 44 , at 16 .

${ }^{13 \%}$ See JA.COBSOHN, supra nate 128 , at 128.
} 
True, all constitutional provisions of unamendability cannot have an absolute effect. In 1918 , A. Lawrence Lowell wrote that "the device of providing that a law shall never be repealed is an old one, but I am not aware that it has ever been of any avail." ${ }^{188}$ Similarly, Benjamin Akzin expressed his skepticism regarding the usefulness of eternity clauses since, if "the demand for change were to become so strong... it is hardly imaginable that its protagonists would renounce their objectives only because the Constitution says that the provision is inviolable." ${ }^{189}$ From a purely factual point, that is certainly correct. "In a conflict between law and power," Hannah Arendt wrote, "it is seldom the law which will emerge as victory." ${ }^{190}$ No constitutional schemes, even thase that expressly attempt to do so, can hinder for long the sway of real or brute forces in public life. ${ }^{191}$ Constitutional unamendability is therefore a question of both norm and fact. ${ }^{192}$ The ability of physical power to force prohibited changes-for example, a forcible annexation of territory, which would violate the territorial integrity or a forcible revolution to overcome unamendability -is unquestionable. From a legal perspective, the question remains whether forced territorial or constitutional changes would be valid according to the constitutional system's standards. ${ }^{193}$

\footnotetext{
${ }^{183}$ A. LAWRENCE LOWELL, GREATER EUROPEAN GOVERNMENTS 103 (1918).

${ }^{13 \mathrm{j})}$ Benjamin Akzin, The Piace of the Constitution in the Modern State, 2 ISR. L. REV. 1, 12 (1967).

${ }^{190}$ HANNAH ARENDT, ON REVOLUTION 142 (2006).

${ }^{191}$ Benjamin Akzin, On the Stability and Reolity of Constitutions, 3 SCRIPTA HIEROSOLYMITANA 313, 332 (1956).

${ }_{192}$ Victor M. Mufíiz-Fraticelli, The Problem of a Perpetuar Constitution, in INTERCENERATIONML JUSTICE 379, 379-80 (A Gasseries and L. Meyer eds., 2009).

${ }^{193}$ Walter F. Murphy, Staggering Toward the New Jerusalem of Constitutional Theory: A Response to Raiph F. Gaebler, 37 Am. J. JuRls. 337, 348 (1992).
} 
Whereas these statements are correct with regard to all provisions of unamendability, they are all the more relevant to the unamendable protection of territorial indivisibility. The constitutional protection of territorial integrity is Janus-faced, looking both externally and internally. Externally, it looks to the relationship between states and to the protection of territorial integrity against external threats and use of force such as armed attacks, annexation, and occupation. Internally, it aims to protect the territory against internal threats, mainly by limiting people's claims to what is termed 'external self-determination' by territorial secession. ${ }^{194}$ There is thus a conceptual difference between the unamendability of territorial integrity versus unamendability of other principles such as fundamental rights, secularism, separation of powers, and the form of government. The latter principles are all under domestic control, regulated by various governmental and institutional bodies, which allow-especially when accompanied by effective mechanisms of judicial review-for the enforcement of provisions of unamendability. For example, the Turkish Constitutional Court was able to protect the unamendable principle of secularism from infringements by governmental attempts to amend the constitution in order to abolish a headscarf ban in universities; ${ }^{195}$ the Czech Constitutional Court managed to protect the unamendable principle of the rule of law by invalidating an ad hoc constitutional act which called early elections by bypassing the established constitutional procedure. ${ }^{196}$ These were instances where unamendable basic constitutional principles were challenged by domestic institutions. Territorial integrity is distinct because it faces a dual threat, internal and external, which is independent of state authority, hence making it more vulnerable than other unamendable principles. If the state fears the voluntary ceding of territory under external pressure or coercion, what could be the utility of an unamendability clause on territorial integrity?

\footnotetext{
${ }^{194}$ See generaily Milena Sterio, On The Right to External Self-Determination: "Selfistans," Secession, and the Great Powers' Rule, 19 MINN. J. INT'L L. 137 (2010); Jure Vidmar, The Annexation of Crimea and the Boundaries of the Will of the People, 16 German LJ. 365 (2015); Amandine Catala, Secession and Annexation: The Case of Crimea, 16 GERMAN L.J. 581 (2015); EL OUALI, supra note 137, at 113-66, 241-94.

${ }^{195}$ See Yaniv Roznai \& Serkan Yalcu, An Unconstitutiond Constitutional Amendment-The Turkish Perspective: A Comment on the Turkish Constitutionol Court's Headscarf Decision, 10 INT'L J. ConsT. L. 175 (2012); Ergun Özbudun, Judicial Review of Constitutiongl Anendments in Turkey, 15 EUR. PUB. L. 533 (2009).

${ }^{19}$ See Yaniv Roznai, Legisorudence Limitotions on Constitutional Amendments? Reflections on the Czech Constitutional Court's Deciaration of Unconstitutionai Constitutional Act, 8 VIENNA J. INI'L CONST. L. 29 (2014); Kieran willams, when a Constitutional Amendment Violates the Substantive Core: The Czech Constitutional Court's September 2009 Early Elections Decision, 36 REv. CEN. \& EAST EUR. L. 33 (2011); Jan Kudrna, Concellation of Early Elections by the Constitutional Court of the Czech Republic: Beginning of A New Concept of "Protection of Constitutionality," 4 JURISPRUDENCLA/JURISPRUDENCE 43 (2010).
} 
First, it may attach the stigma of domestic illegality to the breakaway unit or its annexing state, but that is not a very strong disincentive. Especially, when combined with potentially plausible legitimacy claims, ${ }^{197}$ this deterrent becomes even less effective. Additionally, from an international law point of view, "such constitutional provisions have no legal effect on the international order."

Second, the unamendability of territorial integrity might be regarded as a welcome mechanism for protecting democratic decision-making against "blackmail" by minorities. It allegedly shuts down the option for secession and, at the very least, enhances the bargaining position of those against separatism, if unamendability is not interpreted as providing a duty to uphold the territorial integrity. ${ }^{199}$ As Cass Sunstein suggested, constitutions should not include a right to secede since protecting such a right equips minority groups with a strategic and even dangerous weapon and power of bargaining. ${ }^{200}$ Even if one accepts Sunstein's claim, there is an important difference between not including a right to secede within a constitution or even explicitly forbidding such a right, and absolutely entrenching territorial indivisibility as unamendable. As illker Gökhan Şen writes:

With the exception of [...] rare cases, unilateral secession is forbidden by the quasi-totality of the World Constitutions. This does not exclude, however, the constitutional regulation of the territorial modification of a state. It is not illogical to assume that the constituent power anticipate a future threat to the territorial integrity and prefer to frame a procedure to regulate against such an occurrence. Consequently, numerous constitutions include the referendum device as a condition for secession or other form of territorial alteration that mav prove inevitable and irreversible. ${ }^{201}$

\footnotetext{
197 See aisa Tierney, supra note 17.

${ }^{19 a}$ Christakis, supra note 81 .

${ }^{19 y}$ See, supro note 81 .

${ }^{200}$ See Cass Sunstein, Constitutionalism and Secession, 58 UNI. CHI. L. Rev. 633, 634 (1991)

To Place such a right in a founding document would increase the risks of ethnic and factional struggle; reduce the praspects for compromise and deliberations in government; raise dramatically the stakes of day-today political decisions; introduce irrelevant and illegitimate considerations into those decisions; create dangers of blackmail, strategic behavior; and exploitation; and, most generally, endanger the prospects for lang-term self-government.

${ }^{201}$ ŞEN, supro note 184 , at 142.
} 
The risk is that, in terms of constitutional dynamics, unamendability might serve the exact opposite of its original preservative purpose: Not only does it not prevent the changes, but by blocking any chance of achieving them through peaceful and political means, it encourages the realization of these changes in an extra-constitutional manner ${ }^{202}$ One study demonstrates that the lack of a strategic framework that produces peaceful resolutions to self-determination-based conflicts "grants independence to entities that fight their way to independence, which perpetuates violence and instability. ${ }^{\prime 203}$ According to this perspective, unamendability of territorial integrity is not only ineffective but might also frustrate attempts at peace-making. ${ }^{20-1}$

It is true that unamendability in general may be more effective in ordinary peaceful times than in times of crisis and in states where political players understand that they have to play according to the democratic rules of the game. To that end, unamendability can be described by the metaphor of a lock on a door. ${ }^{205}$ A lock cannot prevent housebreaking by a determined burglar equipped with good burglary tools, and even more to the point, it cannot prevent its own-or the entire door's-destruction by sledgehammer or fire. At the same time, there is no need for the safety measure of a lock if we are dealing solely with honest people, because then there is no fear that any of them will attempt to break into the house. The lock's utility is in deterring those who usually obey the accepted rules when those rules are accompanied by effective safety-measures. When such measures are missing and they are facing an easy opportunity to improve their condition at the expense of others, burglars may succumb to the temptation to exploit this opportunity. Finally, the lock also has a psychological function: It is a mechanism we use in order to reassure ourselves that we are safe and protected.

\footnotetext{
${ }^{202}$ See, e.g., Andrew Friedman, Dead Hond Constitutionalism: The Donger of Eternity Clauses in New Democracies, 4 MEXICAN L. REV. 77, 93-96 (2011).

${ }^{203}$ Williams, Avoryie \& Armstrong, supro note 151, at 21 (contending that territorial conflicts are more likely to recur than other types of conflicts). See Suzanne Werner, The Precorious Noture of Peace: Resolving the issues, Enforcing the Settiement, and Renegotiating the Terms, 43 A.w. J. Pol. Scl. 912, 915, 924 (1999).

${ }^{204}$ Cf. Christakis, supra note Error! Bookmark not defined. ("[F]or Crimea, as probably for other very difficult cases that sour intermational relations... only a solution that is negotiated and freely accepted by all the protagonists will probably bring about a solution to this fierce conflict between unlawful effectivités and the law.").

2 2ils See RoznAl, supra nate 31, at 217.
} 
In the same way, unamendability cannot block extra-constitutional measures. It is also not needed when the socio-political culture is that of self-restraint and lawfulness because, in that situation, there is no fear of an attempt to change the political system's furdamental structures or to abuse power. Unamendability is aimed at preventing the same temptation the burglar faces. Finally, in its aspirational aspect, unamendability makes us feel good about ourselves. Karl Loewenstein was not mistaken in his observation that in ordinary peaceful times, unamendability can function as a useful red light before political actors attempt to change the constitution. In contrast, during times of crisis, unamendability is just a piece of paper which political reality could disregard or ignore. ${ }^{206}$

\section{E. Conclusion}

Before concluding, a few disclaimers are warranted. In this paper, we are arguing neither against nor in favor of the general use of unamendability. ${ }^{207}$ We also acknowledge the importance of territorial integrity and do not argue in favor of or against the right to secede. ${ }^{208}$ We do claim that if constitutional designers wish to use the mechanisms of unamendability, they should reserve it for protecting the most basic principles of the democratic order, which can be enforced and not ignored at will. Unamendability is a "complex and potentially controversial constitutional instrument, which should be applied with care," 209 especially when it is used in order to protect the state's territorial integrity.

\footnotetext{
206 Karl Loewenstein, Constitutions, Constitutional Law, in MARXISM, COMMUNISM, AND WESTERN SOCIETri $\wedge$ Comparative Encyclopedia 169, 180-81 (C.D. Kernig ed., 1972).

${ }^{207}$ In fact, one of us has argued that unamendability rests upon a solid theoretical ground. See RozNAl, supro note 31: Yaniv Roznai, Towards a Theory of Unamendobility (NYU School of Law, Public Law Research Paper No. 15-1, 2015), htto://5srn.com/abstract=2569292. The other has investigated the democratic legitimacy of eternity clauses and found it to vary considerably according to the substance and method of adoption and repeal of such clauses. See Silvia Suteu, Eternity and the Constmution: The Promise and limits of Eternity Clauses (PhD Thesis, forthcoming 2015).

${ }^{21 k^{3}}$ Such recogrition carries its own risks. See christakis, supra note 81 (arguing that "accepting to extend a right of secession to the post-colonial context would open up Pandora's box by allowing the world's 6000 ethnic groups to claim a right of secession").

2(r) Venice Commission for Democracy through Law (Venice Commissian), Report on Constitutional Amendment, CouvClL of Eur. 43 (Jan. 19, 2010), http://www.verice.coe.int/webforms/documents/CDL-AD(2010)001.aspx (last visited June 16, 2015).
} 
Unamendability of territorial integrity is more vulnerable than other principles protected via constitutional eternity clauses. It is subject to the internal threat of secessionist movements and the external threat of forceful annexation, both of which are plausible frames within which to cast the 2014 Crimean crisis. As the latter situation has shown, territorial unamendability is an especially ineffective example of the preservative function of the eternity clause. In fact, unamendability played no direct role in the current crisis, which raises imperative questions regarding the ability or inability of constitutional law to effectively address and regulate issues relating to the indivisibility of a state's territory. Crimea is also a case that exposes the limits of constitutional law and theory in the face of claims of popular sovereignty legitimized, however problematically, via referendums. Given "the deep pathology of uncertainty" in both constitutional and international law in this area and the various "overlapping and conflicting" legal doctrines, ${ }^{210}$ constitutionalizing territorial integrity as unamendable does little to clear the waters.

Additionally, the Ukrainian crisis exposes the vicious cycle at work behind unamendability. We ascribe certain principles as unamendable because we know that these are the most fragile. Samuel Issacharaff is right in claiming that the provisions which "are off the table for internal change generally reflect[] the birth pangs of that particular society." 211 Constitution-drafters design provisions so as to work exactly against the features of a state's tradition and culture which could cause damage through the ordinary political process. ${ }^{212}$ We assign unamendability to those principles which are considered at risk, but unamendability itself cannot provide complete-or, in the case of territorial integrity, perhaps any effective-protection. Ignoring certain unamendable fundamental principles might lead to disrespect of other imperative unamendable principles. Weakening unamendable fundamental constitutional principles widens the gap between constitutional norms and constitutional reality, thereby challenging constitutional supremacy, undermining respect for the constitutional ordering itself, and destabilizing the entire constitution. When territorial integrity is under threat, and the entire constitutional order is jeopardized, our inadequate unamendable "lock on the door" will likely prove of poor make indeed.

\footnotetext{
${ }^{210}$ Tierney, supra note 17.

21 Issacharoff, supra note 140 , at 1430 . In this respect, $\mathrm{kim}$ Lane Scheppele is correct in claiming that constitutions are not only future looking, but also reacting to past events. See Kim Lane Scheppele, A Constitution Eetween Post and Future, 49 WM. \& MMRY L. REV. 1377 (2008).

${ }^{212}$ Cass R. Sunstein, Constitutionalism, Prosperity, Democracy, 2 CONST. POL. ECon. 371, 385 (1991).
} 